\title{
ResearchGate
}

See discussions, stats, and author profiles for this publication at:

https://www.researchgate.net/publication/303634119

\section{Status, trends and drivers of kelp forests in Europe: an expert assessment}

Article in Biodiversity and Conservation - May 2016

Impact Factor: 2.37 · DOI: 10.1007/s10531-016-1141-7

CITATION

READS

1

15

27 authors, including:

\section{Francois Gevaert}

Université des Sciences et T...

38 PUBLICATIONS 339 CITATIONS

SEE PROFILE

Isabel Sousa Pinto

University of Porto

127 PUBLICATIONS 1,409

CITATIONS

SEE PROFILE 


\title{
Status, trends and drivers of kelp forests in Europe: an expert assessment
}

\author{
R. M. Araújo ${ }^{1}$ J. Assis ${ }^{2} \cdot$ R. Aguillar $^{3}$ - L. Airoldi ${ }^{4} \cdot$ \\ I. Bárbara ${ }^{5}$ - I. Bartsch ${ }^{6}$ - T. Bekkby ${ }^{7}$ - H. Christie ${ }^{7}$. \\ D. Davoult ${ }^{8,9} \cdot$ S. Derrien-Courtel ${ }^{10} \cdot$ C. Fernandez $^{11}$. \\ S. Fredriksen ${ }^{12} \cdot$ F. Gevaert ${ }^{13,14} \cdot$ H. Gundersen ${ }^{7}$. \\ A. Le Gal ${ }^{10} \cdot$ L. Lévêque ${ }^{9,15} \cdot$ N. Mieszkowska ${ }^{16}$. \\ K. M. Norderhaug ${ }^{7,12} \cdot$ P. Oliveira ${ }^{1}$ A. Puente ${ }^{17}$. \\ J. M. Rico ${ }^{11}$ - E. Rinde ${ }^{7}$ - H. Schubert ${ }^{18}$ - E. M. Strain ${ }^{19}$.

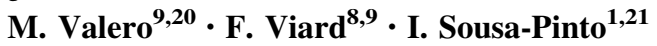

Received: 15 December 2015/Revised: 29 April 2016/Accepted: 12 May 2016

(C) Springer Science+Business Media Dordrecht 2016

\begin{abstract}
A comprehensive expert consultation was conducted in order to assess the status, trends and the most important drivers of change in the abundance and geographical distribution of kelp forests in European waters. This consultation included an on-line questionnaire, results from a workshop and data provided by a selected group of experts working on kelp forest mapping and eco-evolutionary research. Differences in status and
\end{abstract}

Communicated by Stefan Schindler.

This is part of the special issue on Networking Biodiversity Knowledge.

R. M. Araújo

ritaraujo@ciimar.up.pt

1 Interdisciplinary Centre of Marine and Environmental Research, (CIIMAR/CIMAR), University of Porto, Rua dos Bragas 289, 4050-123 Porto, Portugal

2 Centre of Marine Sciences, University of Algarve (CIMAR-Algarve), Campus of Gambelas, 8005-139 Faro, Portugal

3 Oceana, Madrid, Spain

4 Dipartimento di Scienze Biologiche, Geologiche ed Ambientali, (BIGEA) \& Centro Interdipartimentale di Ricerca per le Scienze Ambientali (CIRSA), University of Bologna, UO CoNISMa, Via S. Alberto 163, 48123 Ravenna, Italy

5 Grupo BioCost, Departamento de Bioloxía Animal, Bioloxía Vexetal e Ecoloxía, Facultade de Ciencias, Universidade da Coruña, Campus de A Coruña, 15008 A Coruña, Spain

6 Alfred-Wegener Institute, Helmholtz-Center for Polar and Marine Research, Am Handelshafen 12, 27570 Bremerhaven, Germany

7 Norwegian Institute for Water Research, Gaustadalléen 21, 0349 Oslo, Norway

8 CNRS, UMR 7144 AD2 M, Station, Biologique, Place Georges Teissier, 29680 Roscoff, France

9 UPMC Univ. Paris 6, Station Biologique, Sorbonne Universités, Place Georges Teissier, 19680 Roscoff, France 
trends according to geographical areas, species identity and small-scale variations within the same habitat where shown by assembling and mapping kelp distribution and trend data. Significant data gaps for some geographical regions, like the Mediterranean and the southern Iberian Peninsula, were also identified. The data used for this study confirmed a general trend with decreasing abundance of some native kelp species at their southern distributional range limits and increasing abundance in other parts of their distribution (Saccharina latissima and Saccorhiza polyschides). The expansion of the introduced species Undaria pinnatifida was also registered. Drivers of observed changes in kelp forests distribution and abundance were assessed using experts' opinions. Multiple possible drivers were identified, including global warming, sea urchin grazing, harvesting, pollution and fishing pressure, and their impact varied between geographical areas. Overall, the results highlight major threats for these ecosystems but also opportunities for conservation. Major requirements to ensure adequate protection of coastal kelp ecosystems along European coastlines are discussed, based on the local to regional gaps detected in the study.

Keywords Kelp forests · Expert consultation · Status and temporal trends · Long-term changes $\cdot$ Europe

\section{Introduction}

It is generally accepted that global research and conservation questions related to biodiversity and ecosystem services need to be tackled at national, regional, and local geographical scales relevant to management and policy activities (Petes et al. 2014; Helmuth et al. 2014). Using the best scientific information available to support decision-making is fundamental to the implementation of national and international policies on conservation of biodiversity and sustainable use of resources. Reliable information and adequate scientific data to support the knowledge needs of different groups of stakeholders and decision-makers is not, however, always available (Airoldi and Beck 2007).

10 Station Marine, Muséum National d'Histoire Naturelle, Place de la Croix, BP 225, 29182, Concarneau, France

Dpto. B.O.S. (Ecología), University of Oviedo, 33071 Oviedo, Spain

Department of Biosciences, University of Oslo, P.O. Box 1066, Blindern, 0316 Oslo, Norway

UMR 8187 LOG, Univ Lille Nord de France, Université Lille1, 62930 Wimereux, France

UMR 8187 LOG, CNRS, 62930 Wimereux, France

FR2424, CNRS, Station Biologique, Place Georges Teissier, 29680 Roscoff, France

The Marine Biological Association of the UK, Citadel Hill, Plymouth PL12PB, UK

Environmental Hydraulics Institute (IH Cantabria), Universidad de Cantabria, Avda. Isabel Torres, 15, Parque Científico y Tecnológico de Cantabria, 39011 Santander, Spain

University Rostock, Biosciences, Albert-Einsteinstrasse 3, 18059 Rostock, Germany

Sydney Institute of Marine Science, 19 Chowder Bay Road, Mosman NSW 2088, Australia

UMI 3614 EBEA, UC, UACH, CNRS, Station Biologique, 29680 Roscoff, France

Department of Biology, Faculty of Sciences, University of Porto, Porto, Portugal 
Processes at the interface between science and policy can also have very different structures and approaches. Where a topic requires an in-depth analysis and a consolidated viewpoint from the scientific community and other knowledge providers, integrated activities are required in order to synthesize and analyze existing knowledge. Using such a framework, an EU-funded Coordination Action, "Developing a Knowledge Network for European expertise on biodiversity and ecosystem services to inform policy making economic sectors (KNEU)" was conducted with the objective of designing a Network of knowledge (NoK) on biodiversity and ecosystem services to inform policy-making and economic sectors in Europe (www.biodiversityknowledge.eu/) (see Neßhöver et al. 2016). The NoK provided an interface where knowledge holders were identified and invited to synthesize the available knowledge on given topics identified in a request-driven, sciencepolicy knowledge exchange process (Livoreil et al. 2016). The functioning and operationalization of the NoK was tested within the KNEU project, by examining different casestudies and evaluating results, challenges and main achievements from a range of methodological approaches (Schindler et al. 2014; Dicks et al. 2016; Pullin et al. 2016; Schindler et al. 2016). Within this framework the question: "What is the current status of kelp forests in Europe and what is the evidence that temporal trends in distribution will affect kelp ecosystems' biodiversity and the provision of ecosystem services?" was selected as one of the case studies. This was a broad question covering different sub-topics and was consequently addressed by sub-questions answered using three methodological approaches: expert consultation, systematic review and adaptive management. The expert consultation approach (which is described in this manuscript) was used to assess the status and trends of kelp forests in Europe, giving also some initial insights to the questions addressed by the other methodological approaches.

Kelp forests dominate subtidal shallow rocky coasts and are key components of coastal ecosystems in temperate to polar parts of the world, contributing to their production, biodiversity and functioning (Mann 2000; Steneck et al. 2002; Smale et al. 2013; KrauseJensen and Duarte 2014). These ecosystems include habitat-forming primary producers (both kelps and associated algae species) that support complex food webs in coastal zones and provide food, shelter and habitat for a variety of associated organisms such as apex predators (sea mammals and seabirds), fish and invertebrates (Duggins et al. 1989; Mann 2000; Norderhaug et al. 2005; Reisewitz et al. 2006; Christie et al. 2009; Leclerc et al. 2013, Bertocci et al. 2015). Kelp forests provide several other important ecological functions, supporting high primary production and biomass in the form of detritus that is exported to other ecosystems, including deep-sea sediments, shallow coastal areas, and intertidal rocky shores (e.g. Duggins et al. 1989; Mork 1996; Krumhansl and Scheibling 2012). Finally, kelps have the potential to play an important role in C-sequestration (Chung et al. 2013), since a significant amount of carbon is maintained within kelp forests at any one time (Smale et al. 2016), and some kelp-derived organic matter is exported to other habitats where it may be buried and stored for a considerable amount of time, thereby contributing to natural carbon sequestration (Hill et al. 2015). Collectively, kelp forests are amongst the most diverse and productive ecosystems of the world (Mann 1973) providing many valuable ecosystem services (Costanza et al. 1997).

Over the past two centuries, overfishing has driven widespread declines of kelp forests in some regions through cascading effects on sea urchin abundance (e.g. Jackson et al. 2001; Watson and Estes 2011; Leleu et al. 2012; Steneck et al. 2013). Losses of kelp forest systems have also been reported due to climate change in the last few decades, especially near the low latitude limits of kelp ranges, where they can become eco-physiologically stressed (Steneck et al. 2002; Norderhaug and Christie 2009; Wernberg et al. 2010; 
Fernández 2011; Oppliger et al. 2012; Assis et al. 2013; Brodie et al. 2014). Recent modelling studies predicted severe decline of kelps along a great part of the European coastline and progression into cold temperate to polar areas (Müller et al. 2009; KrauseJensen et al. 2012; Assis et al. 2013; Raybaud et al. 2013). On the other hand, the increase in seawater temperature has also resulted in unfavourable conditions in some areas for overgrazing by sea urchins, resulting in kelp forest recovery in large areas of the NE Atlantic (e.g. Norderhaug and Christie 2009; Rinde et al. 2014). Storms affect kelp mortality (Christie et al. 1998, Smale and Vance 2015), and future increases in storm frequencies due to changes in climate are also likely to affect kelp forest distribution. Other local factors reported to negatively affect kelp forest abundances are kelp harvesting (Christie et al. 1998; Lorentsen et al. 2010), decline of water quality (e.g. pollution, eutrophication, sedimentation) (Airoldi 2003; Delebecq et al. 2013; Strain et al. 2014), diseases and presence of non-native and invading species (Ellertsdóttir and Peters 1997; Williams and Smith 2007).

The dominant seaweed species along the European coastline are brown algae mainly belonging to the Laminariales (kelp) and Tilopteridales (kelp-like) which are distributed from the lower intertidal down to, approximately $30 \mathrm{~m}$ in the subtidal zone, depending on the clarity of the water. In Europe, these orders include the native species Alaria esculenta (Linnaeus) Greville, Chorda filum (Linnaeus) Stackhouse, Laminaria digitata (Hudson) J.V. Lamouroux, L. hyperborea (Gunnerus) Foslie, L. ochroleuca Bachelot de la Pylaie, L. rodriguezii Bornet, L. solidungula J. Agardh, Saccharina latissima (Linnaeus) C.E. Lane, C. Mayes, Druehl and G.W. Saunders, Phyllariopsis brevipes (C. Agardh) E.C. Henry and G.R. South, P. purpurascens (C. Agardh) E.C. Henry et G.R. South, Saccorhiza polyschides (Lightfoot) Batters, S. dermatodea (Bachelot de la Pylaie) and the introduced kelp species Undaria pinnatifida (Harvey) Suringar.

The aim of this study was to assemble and analyse European kelp expert's knowledge and data on status and trends of kelp distribution through the established NoK on biodiversity and ecosystems in the KNEU project (Schindler et al. 2016). In spite of the importance of kelp forests for the functioning of coastal ecosystems (Steneck et al. 2002), there is currently no coordinated monitoring of kelp forests at EU level, and only limited monitoring and hence few data on kelp distribution at local, regional or national scale. The available information about European kelp forests, such as current distribution, temporal trends and important drivers, is thus fragmented and outdated (Smale et al. 2013). In this study available knowledge was assembled directly from kelp experts through a questionnaire on different aspects related to kelp forest distribution and temporal trends in Europe. Additional data and information on drivers of change and gaps were collated through a workshop and a mapping exercise.

\section{Materials and methods}

\section{Expert opinion survey}

\section{Scoping}

Forty-six knowledge hubs were contacted via e-mail and asked to identify a group of relevant experts on European kelp forests. The selection of the knowledge hubs was based 
on their connection to environmental conservation, marine environment and research on natural/environmental sciences and/or marine related topics.

\section{Questionnaire design and distribution among experts}

A questionnaire (Table 1) was developed comprising seven questions on different aspects of current trends in kelp distribution in Europe, and the main involved drivers and ecosystem impacts. The experts answered the questions for their geographical working area. Question 7 aimed to assess the expert's opinion of the trends on a global scale. For all questions, except no 6 , the experts had the possibility to choose more than one category of the predefined answers, and five of the questions included the expert's lack of knowledge on the subject. In question 6, the aim was to identify conservation efforts and management programs for kelp forest within the experts working area.

The questionnaire was made available on-line and the experts were given 3 weeks to answer. Reminders were sent once to those who did not reply the first time.

\section{Workshop}

Following the completion of the questionnaire, a workshop was organized to present the results and to discuss the next steps of the study within a working group of experts. Fifty-

Table 1 List of questions comprising the questionnaire given to the expert group, covering different aspects of the status and current trends of kelp forests in Europe as well as their drivers and ecosystem impacts

Question Question
no.

1 Current trends in kelp forests (regarding extension and density)

Source of information used by experts to answer to question 1

Opinion about the relevant stressors acting in each geographical region
Opinion on the effects of the observed kelp trends in fisheries

Identify the ecosystem characteristics or services affected by the observed trends in kelp forests

Identify conservation efforts/management programs for kelp forests currently running in their study area

Describe the current trends in kelp forests at a global scale
Four categories of answers: increasing, decreasing, stable, I dońt know

Five categories of answers: scientific works, own quantitative data, non-scientific information obtained from locals, fisherman's, divers, harvesters, others

Seven categories of answers: pollution, fishing pressure/gear, kelp harvesting, biological invasions, sea urchins/herbivores, global warming, others

Four different categories of answers: increase, no effects, decrease, I dońt know

Four different categories of answers: biodiversity, interest of divers (tourism), water quality, others.

Three different categories of answers: yes (if the participants choose this option they were further asked to succinctly describe these programs), no, I dońt know

Five possible categories of answers: increasing, stable, decreasing, increasing in some regions and decreasing in others, I dońt know 
five experts were invited to participate in the workshop and eight (in some cases representing a group of experts) from six different countries (Portugal, Spain, Italy, France, Germany and Norway) attended (15\% of total). At the workshop, the knowledge and data provided by the questionnaire were discussed and a working group was organized to finalize the subsequent collection of required data.

From the initial list of experts indicated by the knowledge hubs and invited for the workshop, 20 representative experts were contacted to be part of the working group that was in charge of mining any data available on kelp distribution (past and present) and kelp abundance within their study area. This information was combined and represented in a map illustrating the current scientific knowledge about kelp forests distribution and trends in Europe. Three additional experts were contacted to provide data and knowledge, either because they represented missing countries with kelp forests or due to their expertise in the field.

\section{Mapping}

A georeferenced grid (resolution of $0.25^{\circ}$ ) was sent to the 20 experts that participated in the second phase of the expert consultation to map kelp forest distribution in their assigned area. Each cell had a unique identification number, to facilitate the subsequent unification in a general grid for Europe. An excel file (Table 2) was also sent to each experts group to compile georeferenced information/data about past and current patterns of occurrence and abundance (e.g. area, biomass, density, depth distribution) for each known kelp species in their area. The information was summarized in one of the following categories: "reduction", "expansion", "stable" (when a decrease or increase trend or a stable population respectively, has been documented by abundance data, recorded in at least two different points in time), or "extinction" (when available presence/absence or abundance data had documented the complete disappearance of a species from a grid cell in which it was previously present). For grid cells where no data on temporal trends were available (presence/absence data) the categories "presence-no status" (when presence data were available for only one temporal record) and "presence-stable" (when presence data were available from more than one temporal record) were represented. For grid cells where no trends or presence data were available the categories "absence" (when the absence of the

Table 2 Fields included in the excel file to be filled with information about the grid cell(s) in the map

Categories

Name of the species the information applies to

Number of grid cell(s) in the map

Name of location/region

Mode of data (model based/observation)

Date of record

Date of comparison with (if available)

Type of data: presence or trend, in area, biomass, density, depth distribution, or any other recorded change Bibliographic reference

Contact institution and contact person

Other remarks 
species was recorded and no previous record of presence was available) and "no data" (when information about the species was not available) were represented. GIS maps summarized the expert information for each cell and species. A scale was created to classify the degree of certainty of the data provided by experts, comprising the three following classes: 1 (high certainty): data based on field observations; 2 (medium certainty): data based on statistical and rule based models; 3 (low certainty): data based on expert judgement or on old records not confirmed by recent surveys.

To improve the spatial coverage of our distribution maps, occurrence data for all kelp species available in the Global Biodiversity Information Facility (GBIF) biodiversity information portal (http://www.gbif.org) and the Ocean Biogeographic Information System (OBIS) database were downloaded and integrated. These data were quality-controlled by eliminating records with a coarser resolution than the grid cells used in this study or falling outside the study area (e.g. terrestrial sites). However, the degree of certainty of the GBIF and OBIS data was not assessed in this study.

The temporal and spatial resolution of the data, and the kelp species covered by the study, are summarized below for each area.

\section{Kongsfjorden (Svalbard)}

Data for Kongsfjorden (western Spitsbergen, Svalbard archipelago, Norway) were based on two comparative quantitative diving investigations along a depth transect off a location called Hansneset from 1996/98 and 2012-2014 and included records of the species $A$. esculenta, L. digitata, L. solidungula, Saccharina latissima and Saccorhiza dermatodea (Hop et al. 2012; Bartsch et al. 2016). Replicate quadrats of either $0.5 \times 0.5$ or $1 \times 1 \mathrm{~m}$ $(n=3-6)$ have been randomly collected along a depth gradient between 0 and $15 \mathrm{~m}$ and biomass, abundance and depth distribution of all species was determined and compared between time periods. The study in 1996/98 covered three seasons (spring, summer, autumn) while in 2012-2014 sampling took place in summer (June-August). Details upon site, sampling and overall biodiversity are given in Hop et al. (2012), Fredriksen et al. (2014), Paar et al. (2015) and Bartsch et al. (2016).

\section{Norway}

Data for the Norwegian coast represent the status and trends of the dominating forest building species L. hyperborea (for the whole coastline) and Saccharina latissima (for southern Norway; data on status and trends for northern Norway are lacking). The Norwegian coast hosts additionally other kelp species as well (A. esculenta, L. digitata, Saccorhiza polyschides, $S$. dermatodea), but data on their distribution and temporal trends were very sparse, hence these species were not included. Field observations (underwater camera or diving) were available for both species in some areas, other areas were covered by distribution models and some by expert judgement (i.e. knowledge by scientists about an area/region that is not available as georeferenced data). Distribution models were either envelope models or spatial predictive models. The envelope models were developed by extrapolating knowledge from field observations of the distribution of the species along depth and wave exposure gradients within each of main ecoregions (Rinde et al. 2006). The spatial predictive models were built on field observations of presence and absence of the species and statistical analyses of the distribution along geophysical gradients (following the methods of Bekkby et al. 2009). 
For L. hyperborea most of Norway was covered by the envelope model (Rinde et al. 2006; Gundersen et al. 2010). For some of the grid cells field observations were also available. In some smaller areas on the West coast of Norway a spatial predictive model was built. The southern border of Laminaria hyperborea kelp loss caused by sea urchin grazing was assessed based on field observations in 2011, as described in Rinde et al. (2014). A grid cell was defined as "reduction" (i.e. having lost L. hyperborea kelp due to sea urchin grazing) if the whole or parts of the grid cell was within sheltered or moderately wave exposed areas (Norderhaug and Christie 2009).

The knowledge of the distribution of Saccharina latissima in mid and northern Norway is poor; hence no data on this species were included in the grid cells for this area. For $S$. latissima, most areas were covered by the rule based model of Gundersen et al. (2012). In some areas at the West coast of Norway expert judgement was applied due to lack of input model coverage (some grid cells also had observations to support the expert judgement). In Skagerrak and the southern part of Norway, more data were available (Moy and Christie 2012), and the distribution and status of S. latissima were here based on a spatial predictive model (Bekkby and Moy 2011).

\section{German coast North sea and the Baltic sea}

Data for the North Sea German coast were only available for the island of Helgoland which is the only natural rocky substrate in the German Bight. The data indicated changes in all three kelp species present (L. hyperborea, L. digitata and S. latissima), based on two quantitative diving investigations in 1967/68 and 2005. This enabled a comparison of trends in biomass, density and depth distribution of these species along the depth gradient (Lüning 1969, 1970; Pehlke and Bartsch 2008). For the German Baltic Sea coast, quantitative diving surveys were carried out in 2003/04 comparing abundance and coverage of L. digitata and S. latissima along depth transects with historical data (Schories et al. 2005).

\section{$U K$}

Data for the UK coastline were obtained from the MarClim project and the Centre for Environmental Data and Recording (CEDaR). The MarClim project surveys 120 timeseries intertidal sites annually (Mieszkowska et al. 2006, 2014) and includes data between 2002 and 2012. The CEDaR data comprised various SCUBA and ROV surveys that were undertaken between 1975 and 2012. For MarClim the abundance of A. esculenta, L. digitata, L. hyperborea, L. ochroleucha, S. latissima, S. polyschides and U. pinnatifida was recorded using the categorical SACFOR scale $(\mathrm{S}=$ Superabundant, $\mathrm{A}=$ Abundant, $\mathrm{C}=$ Common, $\mathrm{F}=$ Frequent, $\mathrm{O}=$ Occasional, $\mathrm{R}=$ Rare). Since data from the MarClim project did not include subtidal sampling and data from CEDaR have a coarse spatial resolution these databases were used only as presence records.

\section{North coast of France}

For the French coast, data were available on abundance (density and/or biomass) of the dominating forest building species L. digitata, L. hyperborea, L. ochroleuca, S. latissima and $S$. polyschides as well as for the non-native species $U$. pinnatifida. Most of these data were collected from 2004 to 2014 during three programs: the project ECOKELP, the monitoring network REBENT and the EU Water Framework Directive survey of coastal 
waters. For native kelps, additional data were gathered from 1995 to 1998 (Billot et al. 1999) and in 2011 (Robuchon et al. 2014). For the REBENT program, the density data were obtained from direct counting by divers in 4139 sampled quadrats of $50 \times 50 \mathrm{~cm}$. Along the coasts of Brittany, 38 sites were studied, including very sheltered (estuaries or gulfs), sheltered (sea inlets or bays), semi-exposed (coastal water) and exposed (offshore) sites. These data were collected since 2004 (Derrien-Courtel 2008; Derrien-Courtel et al. 2013), but additional data have been collected since 2007 for EU Water Framework Directive assessments (Le Gal and Derrien-Courtel 2015). For the northern part of the Eastern English Channel, data of presence/absence (Dizerbo and Herpe 2007), density and/ or biomass of $L$. digitata and S. latissima were obtained from quantitative diving investigations using quadrats of $1 \times 1 \mathrm{~m}$ (data collected in 1996/97 and 2001; Gevaert 2001; Dizerbo and Herpe 2007; Gevaert et al. 2008 as well as unpublished and observational data from field records in 2006, 2008 and 2014, undertaken within the EU Water Framework Directive). Additionally, abundance (density and/or biomass) of L. hyperborea and $L$. digitata for some sites in Brittany within an area of $2800 \mathrm{~m}^{2}$, was evaluated semi quantitatively according to a scale ranging from 1 to 4 (1: less than one sporophyte $/ \mathrm{m}^{2}$ and 4 : maximum cover of the substratum), by randomly positioning 12 quadrats of $0.25 \mathrm{~m}^{2}$ by diving in a circle of $30 \mathrm{~m}$ around the boat. For Roscoff more precise estimates of density and biomass were performed in three sites dominated by L.digitata by counting individuals and weighting fresh material in a total of $840.25 \mathrm{~m}^{2}$ quadrats.

For $U$. pinnatifida, presence data along the French and Brittany coasts were gathered in the course of two programmes from the Brittany Region (CAIN and WAKLIFE ARED projects), the project ECOKELP and Interreg IVA Marinexus programme as well as from observational data published in reports (e.g. Girard-Descatoire et al. 1997; Le Roux 2008; Castric 1996; Derrien-Courtel and Catherine 2012) or from unpublished data (DerrienCourtel, pers. comm.). Specific field surveys using diving were carried out in some areas (e.g. bay of St-Malo, Ushant Island, Morlaix Bay) based on a grid approach, using a mesh size of roughly 1-2 square nautical miles (Grulois 2010; Grulois et al. 2011).

\section{Iberian Peninsula, Mediterranean and Adriatic sea}

Along the Asturian coast data were collected both in the intertidal and subtidal. Intertidal data consisted of abundance (density and biomass $/ \mathrm{m}^{2}$ ) at 20 localities covering the entire coast (Fernández 2011; Fernández pers. comm.). Subtidal data were recorded as percentage cover of $2 \times 2 \mathrm{~m}$ plots placed along 12 transects, done between 0 and $25 \mathrm{~m}$ depth, along $150 \mathrm{~km}$ of the west coastline (Rico et al. 2009; Rico pers. comm.).

Data from the Basque country $(250 \mathrm{~km}$ of coast) were collected by averaging the percentage cover of $31 \times 100 \mathrm{~m}$ long subtidal transects (N. Muguerza and J.M. Gorostiaga, pers. com.).

For the Galician coast, data of presence/absence and abundance were included for Chorda filum, L. hyperborea, L. ochroleuca, P. brevipes subsp. pseudopurpurascens, $P$. purpurascens, S. latissima, S. polyschides and U. pinnatifida by comparing peer-review literature records (Hamel 1928; Miranda 1931, 1934; Bescansa Casares 1948; Seoane Camba 1957; Fischer-Piette and Seoane-Camba 1962, 1963; John 1968; Pérez-Cirera 1975, 1976; Gili et al. 1982; Pérez-Cirera and Maldonado 1982; Polo et al. 1982; Gallardo and Margalet 1992; Granja et al. 1992; Bárbara 1994; Bárbara and Cremades 1996; Izquierdo Moreno 1998; Veiga et al. 1998; López Varela 2000; Otero-Schmitt and Pérez Cirera 2002; Cremades et al. 2006), unpublished and observational data and photographs, 
as well as herbaria information (Herbario de la Universidad de Santiago de Compostela $(\mathrm{SANT})$ ).

In other areas of the Iberian Peninsula (Mediterranean, Gulf of Cádiz, Portuguese and Spanish seamounts and Gulf of Biscay), subtidal data were collected, using both divers and $\mathrm{ROV}$, and combined with literature references.

For the Portuguese coast, observational data (presence/absence) were available for $L$. hyperborea, L. ochroleuca, S. latissima, S. polyschides and U. pinnatifida. For S. polyschides, trends were assessed for its southern distributional range, by comparing literature records reporting the presence of the species in the 1960́s (Ardré 1970) and observational data in 2008/2010 (Assis et al. 2009, 2013). The trends for S. latissima were assessed by comparing reports in the 1960́s (Ardré 1970) and observational data in 2002/2003 (Araújo et al. 2009) with the current distribution of the species in the northern Portuguese coast (2014/2015).

Around the Alboran Island and the Gorringe Bank, data were collected with ROV at a maximum depth of $78 \mathrm{~m}$ for $L$. rodriguezii (in the Mediterranean) and $84 \mathrm{~m}$ for $L$. ochroeluca and $S$. polyschides (both in the Mediterranean and the Atlantic). Kelp distribution on banks (Bermeo and Niebla in Galicia) and around Galician islands (Cies, Salvora, Sisargas, etc.) was also documented by ROV down to $46 \mathrm{~m}$. Other areas including the Galician, Asturian and Andalucian (both Mediterranean and Atlantic) coasts as well as some of the islands (Alboran, Gorringe, Sisargas, etc.) were surveyed by diving up to a maximum depth of 30-40 m. In total, more than 200 dives were performed, considering both ROVS (each dive covered an area of approximately 1000-1300 $\mathrm{m}^{2}$ ) and divers.

Data from the Adriatic Sea on the distribution and abundance of L. rodriguezii were derived from a distribution map by Zuljevic et al. (2011). These data were collected via trawling (1948, 1949, 1956-1961, 1996, 2002), grab (1998) and subsequent ROV (2010) surveys undertaken at 120-260 m depth (Zuljevic et al. 2011).

Data from the Mediterranean coasts of France, Tunisia and the west-south coast of Italy were gathered from either published or grey literature: the latter comprised a variety of sources, including species lists from Natura 2000 designated sites. Data of L. rodriguezii from Corse and Tunisia were derived mainly from Boudouresque and Perret (1977) who summarised data from past sources (Molinier 1960; Fredj 1972). Most of these data are qualitative records of the presence of $L$. rodriguezii obtained during diving expeditions at depths between 70 and $130 \mathrm{~m}$. The only recent records of presence were at fishing grounds in Tunisia (Quetglas and Morales-Nin 2004, average depths 75-80 m) and its observation during a diving at $70 \mathrm{~m}$ at the Banc du Magaud (Pedel and Fabri 2011). Data of $L$. rodriguezii from Italy were derived mainly from Giaccone et al. (2009), who summarised data from past sources (Giaccone 1967, 1970; Andrei 1966 (herbarium sheet); Pignatti and Rizzi Longo 1972; Suriano et al. 1992; Marino et al. 1999, among others). Data for $L$. ochroleuca and $S$ polyschides from the Strait of Messina were derived from Zampino and Di Martino (2001), who compared their mapping with past data from Mojo and Buta (1971), Drew (1974) and Di Geronimo (1987).

Additionally, presence/absence data of L.digitata, L.hyperborea, S. polyschides and $L$. ochroleuca at the scale of Brittany, France and Europe were compiled from a dataset collected for population genetics analyses, from where low genetic diversity and absence of connectivity was considered as an indication of small size and vulnerable populations. In each population/site, 30-50 individuals were sampled along a $50 \mathrm{~m}$ transect. For $L$. hyperborea, S. polyschides and L. ochroleuca data collected referred to one temporal record, while for L. digitata, data on temporal trends were available for some of the grid cells between 1995 and 1998 (Billot et al. 2003) and 2005-2008 (Valero pers. com.). 


\section{Results}

\section{Scoping}

Six out of the forty-six $(13 \%)$ contacted knowledge hubs provided a list of relevant experts on kelp forests in Europe (Euromarine, UNEP-World conservation monitoring center, GEO BON-biodiversity observation network, International Association for Ecology, IUCN Invasive Species Specialist Group and Diversitas). The knowledge hubs nominated sixty-nine experts, from ten countries across Europe (Norway, Sweden, Ireland, England, Scotland, France, Spain, Germany, Portugal, Italy). Some of the countries were over represented (e.g. Norway with sixteen experts) compared to other countries that had a low number of experts on the list (e.g. Sweden, Scotland and England, with only one expert each). Research and academic institutions were over-represented compared to NGOs, companies or management and political institutions. This is explained by the dominance of research related knowledge hubs answering to the call for nomination of experts.

\section{Questionnaire}

The questionnaire was sent to the sixty-nine experts indicated by the knowledge hubs, from which fifty-two responded ( $75 \%$ response rate). The outcomes of the questionnaire were as follows:

\section{Question 1: current trends}

According to the experts' opinions the distribution and density/abundance of individual native kelp species is declining in southern European areas (Northwestern Iberian Peninsula, Gulf of Biscay and Mediterranean sea), with exception of the Southern Iberian Peninsula where no increasing or decreasing trends were indicated (Table 3). For the other geographical regions, different trends were identified, depending on the species considered. Norwegian experts reported an overall increasing trend in density and extension of kelps in

Table 3 Current trends of kelp forests extension and density in the study areas as categorized by the experts

\begin{tabular}{|c|c|c|c|c|c|c|c|c|c|c|}
\hline & \multicolumn{5}{|c|}{ Extension } & \multicolumn{5}{|c|}{ Density } \\
\hline & A & $\mathrm{B}$ & $\mathrm{C}$ & $\mathrm{D}$ & $\mathrm{E}$ & A & B & $\mathrm{C}$ & $\mathrm{D}$ & $\mathrm{E}$ \\
\hline Spitsbergen (1) & 0 & 0 & 0 & 0 & 100 & 0 & 0 & 0 & 0 & 100 \\
\hline Norway (12) & 47 & 20 & 33 & 0 & 0 & 20 & 13 & 47 & 0 & 0 \\
\hline Germany (1) & 0 & 0 & 0 & 0 & 100 & 0 & 0 & 0 & 0 & 100 \\
\hline UK/Ireland (5) & 0 & 0 & 40 & 60 & 0 & 0 & 0 & 40 & 60 & 0 \\
\hline N France (9) & 0 & 40 & 40 & 10 & 10 & 0 & 30 & 40 & 20 & 10 \\
\hline NW Iberian Peninsula (4) & 0 & 91 & 9 & 0 & 0 & 0 & 82 & 0 & 18 & 0 \\
\hline S Iberian Peninsula (5) & 0 & 0 & 50 & 50 & 0 & 0 & 25 & 25 & 50 & 0 \\
\hline Azores (1) & 0 & 0 & 0 & 100 & 0 & 0 & 0 & 0 & 100 & 0 \\
\hline Mediterranean (3) & 0 & 100 & 0 & 0 & 0 & 0 & 100 & 0 & 0 & 0 \\
\hline
\end{tabular}

The numbers are presented as percentages of the total answers from the experts. The number of experts is represented in brackets). A, Increasing; B, Decreasing; C, Stable; D, Dońt know; E, Depends on species 
moderately wave exposed areas in northern Norway due to the recovery of L. hyperborea during the last decades in previously sea urchin grazed areas. However, even in these areas sea urchins grazing by Strongylocentrotus droebachiensis is observed in some places, particularly in the more sheltered areas, and the distribution of kelp is somewhat reduced compared to the pre-grazing period. For the northernmost part of the Norwegian coast $L$. hyperborea kelp only prevails in wave exposed areas and barren grounds still dominates in moderately exposed areas. French experts reported a decreasing trend or stability of $L$. hyperborea beds in Brittany and a general decrease in L. digitata and S. latissima in Northern France (eastern English Channel and Dover Strait), even if some areas were characterized by a relative stable kelp distribution, such as Iroise/Ushant Sea and North Brittany. In contrast, the distribution and density of $U$. pinnatifida was indicated to be expanding spatially and increasing along the French coast. Similarly, German experts reported a biomass increase in L. hyperborea in the southern North Sea (isle of Helgoland) and concomitant slight decline of S. latissima and L. digitata. For UK and Ireland a high degree of uncertainty regarding kelp trends was reported by experts (Table 3).

\section{Question 2: source of information}

Own qualitative observations were the main source of information (34\%) used by experts to base their opinion about the trends of kelp forests in their geographical working area. Additional sources of information such as papers (27\%), information transmitted by locals $(20 \%)$ and own quantitative data $(18 \%)$ were also referred.

\section{Question 3: relevant stressors}

In all geographical areas, multiple stressors acting on the kelp forests were identified. The category and the number of stressors varied between geographical areas (Table 4), and in e.g. Norway all stressors categories were reported to be present. Global warming was the dominant stressor identified by most experts. However, other factors were also reported as highly relevant in some geographical regions; pollution and fishing pressure in the Southern Iberian Peninsula, sea urchin grazing and pollution (i.e. eutrophication) in Norway, and kelp harvesting in Brittany, France (Table 4). Besides the stressors

Table 4 Number of experts selecting the most important stressors potentially affecting kelp forests within each region

\begin{tabular}{llllllll}
\hline & Pollution & Fishing & Harvesting & Invasions & Herbivory & Warming & Others \\
\hline Spitsbergen (1) & 0 & 0 & 0 & 0 & 1 & 1 & 1 \\
Norway (12) & 5 & 1 & 3 & 2 & 8 & 6 & 2 \\
Germany (1) & 0 & 0 & 0 & 0 & 0 & 1 & 1 \\
UK/Ireland (5) & 2 & 0 & 0 & 2 & 0 & 4 & 1 \\
N France (9) & 2 & 0 & 6 & 1 & 0 & 8 & 1 \\
NW Iberia (4) & 0 & 0 & 0 & 0 & 0 & 9 & 5 \\
S Iberia (5) & 3 & 3 & 0 & 0 & 1 & 1 & 2 \\
Azores (1) & 0 & 0 & 0 & 1 & 0 & 1 & 0 \\
Mediterranean (3) & 2 & 1 & 0 & 0 & 1 & 3 \\
\hline
\end{tabular}


categorized in the questionnaire other stressors were identified as relevant for some geographical areas such as water turbidity (France, Mediterranean, Portugal), oscillation in regional oceanographic patterns (Portugal), diseases (Gulf of Biscay), shoreline constructions (Mediterranean), eutrophication (Norway, UK), changes in habitat characteristics (Mediterranean), competition with algal turfs (Mediterranean) and enhanced UV radiation (Portugal).

\section{Question 4: effects on fisheries}

There was a major knowledge gap concerning the effects of changes in kelp forests on fisheries at the European level. The majority of the experts (79\%) reported ignorance about the possible influence of kelp trends on fisheries. The rest of the respondents gave approximately equal score to the other options available; decrease $(10 \%)$, no effect $(6 \%)$ or increase $(6 \%)$.

\section{Question 5: ecosystem characteristics or services affected}

Biodiversity was identified to be the most important ecosystem characteristic affected by the current trends in kelp forests $(52 \%)$. Although much less frequent, other ecosystem characteristics and services such as water quality (13\%), interest of divers (11\%), carrying capacity $(1.5 \%)$ and commercial interest $(1.5 \%)$ were also indicated and $22 \%$ of the experts did not answer this question.

\section{Question 6: conservation efforts/management programs}

Most of the experts reported that there were conservation programs for kelp forests in their study area with exception of experts from Portugal, Mediterranean and Adriatic Sea. In France, these conservation programs included the creation of a Marine Protected Area, "Parc Naturel Marin d'Iroise", in the Iroise/Ushant Sea, the management of harvesters' efforts and processors of kelp and the development of monitoring programs (REBENT, EU Water Framework Directive). In the Azores and Southern Iberian Peninsula, the creation of protected areas was identified to be the main conservation effort. In the Bay of Biscay, experts referred the creation of a joint assessment program between the regional government and the University of Oviedo. For the UK, experts reported the existence of controlling measures on the mechanical harvesting of kelp and the creation of marine protected areas in England. German kelp forests in the North Sea are within a Marine Protected Area but there is no specific program targeting on kelp forests conservation. Regular quantitative monitoring of kelp stands in Germany takes place within the EU Water Framework Directive and, for the Baltic Sea, within the HELCOM-monitoring program. For Norway, efforts on kelp conservation were mainly related with monitoring programs of coastal areas and kelp harvested areas, management plans for kelp harvesting and some monitoring of the recovery process in previously grazed areas.

\section{Question 7: global trends}

When asked to identify the global trends in kelp forests, the majority of the experts answered that kelp forests were decreasing in some regions and increasing in others $(65 \%)$. Some experts however stated that kelp forests were globally decreasing $(25 \%)$, 
while a minority suggested a stable trend $(2 \%)$ and $8 \%$ of the experts answered they did not know.

\section{Mapping}

After discussion on the knowledge collected from the questionnaires, georeferenced data were obtained from experts and collated in an excel database, based on the data entries provided by experts. The results of the data collection showed, that most data available for Europe were qualitative (presence/absence data) and with low temporal resolution, thereby, in most of the cases, it was not possible to use the data to identify quantitative trends (Fig. 1). Data on trends, when available, referred mostly to small parts of the coast and were only available for a few kelp species present in Europe. The exceptions were $S$. latissima and L. hyperborea along the Norwegian coast, for which models have been used to calculate temporal trends (Fig. 2). The mapping exercise revealed a huge lack of temporal datasets with high spatial coverage for most of the regions in Europe, including for the non-native kelp U. pinnatifida (reported in the top 100 of the IUCN invasive species list), although most of the data used for the mapping of kelp forests in Europe had high degree of certainty (Fig. 1). Considering species individually, the data obtained from experts showed that some species are far better studied than others and that a general trend for kelp species in Europe is difficult to identify, as the trends vary locally and between species and geographical regions. Species with very low representation in terms of available datasets were excluded from this part of the study.

Alaria esculenta is distributed in Europe from France (south of the Pointe du Raz; Castric-Fey et al. 2001) to Svalbard (Fredriksen et al. 2014). Data received on the distribution of this species referred almost exclusively to the UK and the central coast of Europe, showing small scale variations in trends for some isolated locations but the available records refer mainly to presence/absence data (Fig. 2a). The records available for the northern area of distribution of the species (Svalbard) show no significant decrease in biomass.

Saccharina latissima is found from Svalbard (Gulliksen et al. 1999) to Portugal (Araújo et al. 2009). There are relatively few temporal data available for this species across its
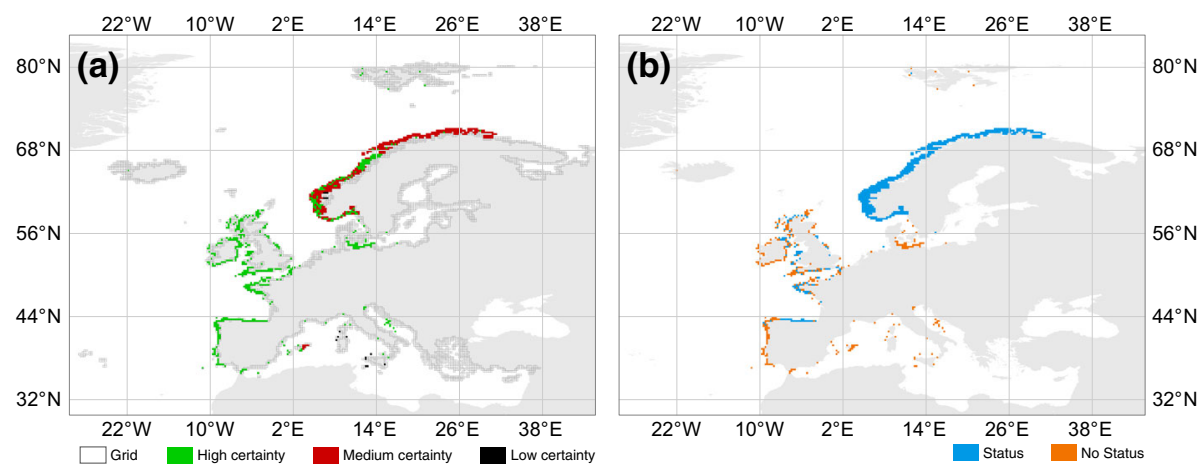

Fig. 1 Map showing the results of the mapping exercise with respect to a the degree of certainty of the data provided by experts: green high certainty; red medium certainty and black low certainty and $\mathbf{b}$ to the type of data provided by experts for each geographical region. Orange no data available on trends. Blue data available on trends 

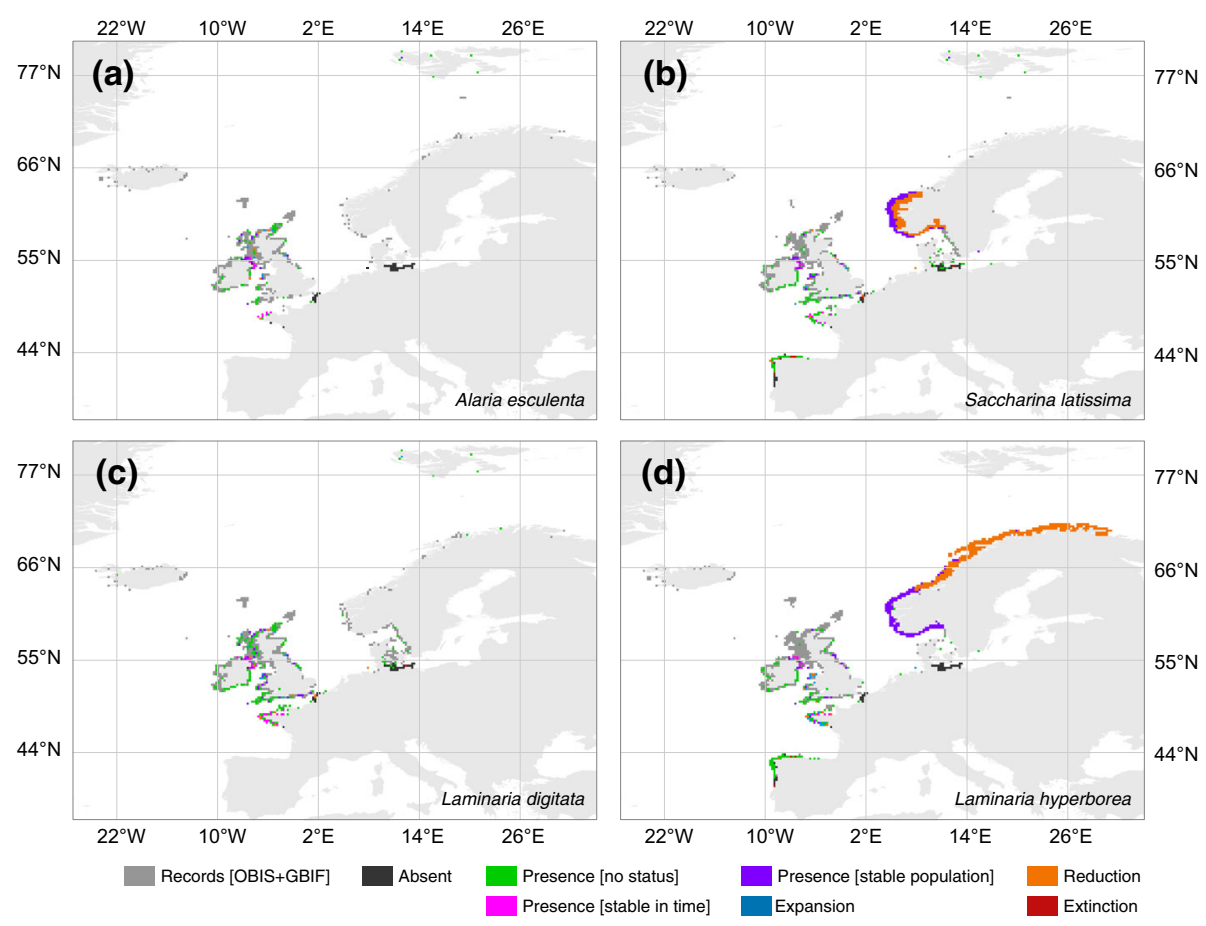

Fig. 2 Map showing the results of the mapping exercise for the following kelp species: a Alaria esculenta; b Saccharina latissima; c Laminaria digitata; d Laminaria hyperborea

range, except from Norway (Fig. 2b). The available data showed that the abundance of $S$. latissima is decreasing in some areas (e.g. eastern English Channel and Dover Strait with successive periods of local extinction, Gevaert, pers. com.), stable in other areas such as the outer part of the Norwegian coastline or increasing (e.g. due to recovery from sea urchin grazing) (Fig. 2b). In the Bay of Biscay the extinction of the S. latissima populations in some localities has been documented. In Portugal, the qualitative data available show that populations of $S$. latissima shifted in depth, being currently absent from the low intertidal and restricted to the subtidal level (Araújo, pers. comm.). Similarly, on Helgoland, North Sea this species has undergone a reduction in biomass and changed in depth occurrence from major stands at the sublittoral fringe to deeper stands at 4-5 m depths (Lüning 1970; Pehlke and Bartsch 2008). In northern Europe large areas of S. latissima have, since the late 1990s, been lost in the Skagerrak region (Bekkby and Moy 2011; Moy and Christie 2012). In south-western Norway, the trend of decrease was not so pronounced, although large areas were also lost here (Moy and Christie 2012), mainly in the inner and more sheltered parts, while the outer and less sheltered parts remained intact and stable (Norderhaug et al. 2015a). After 2005, the S. latissima kelp forests showed some signs of recovery but are still at a reduced level in Skagerrak (Moy et al. 2015) and the southern North Sea coast (Norderhaug et al. 2015b). In sheltered areas of northern Norway this species could have been heavily decimated due to sea urchin grazing, but no information is available about the distribution of this species before the grazing event took place (early 1970s), and the extent of this potential loss is unknown. In Kongsfjorden (western 
Spitsbergen), the species slightly reduced its depth extension but overall biomass kept constant (Bartsch et al. 2016).

For the Baltic, where the species reaches its salinity limits on the underwater reefs east of the Island of Rügen (Adlergrund), no loss of occurrence was observed within the last two decades. Before this period, a pronounced upward vertical shift by several meters for both, the lower as well as the upper limits was reported by Breuer and Schramm (1988).

Laminaria digitata is distributed from France (Silberfeld et al. 2011) to Svalbard (Fredriksen et al. 2014). Data for this species were available mainly for the central Europe (Fig. 2c). In France, the status of $L$. digitata remains uncertain but in Brittany some local surveys clearly showed population regressions for small, isolated populations (Couceiro et al. 2013) or at their southern range limit (Oppliger et al. 2014), with no evident link to harvesting (Valero et al. 2011, Derrien-Courtel pers. comm.). Populations of L. digitata in the eastern English Channel and Dover Strait are now extinct on the French coastline (Gevaert, pers. comm.) and are under pressure in the southern North Sea (Bartsch et al. 2013). In Kongsfjorden (western Spitsbergen, Svalbard) this species considerably increased in biomass since 1996/98 at shallow sublittoral depths (Bartsch et al. 2016).

Laminaria hyperborea kelp forests are widely distributed along the European coasts from the Portuguese coast in the south (Araújo et al. 2009) to the Murman coast in Russia in the north (Schoschina 1997). Data on L. hyperborea trends are available mainly for Norway, showing variable trends of decrease or stability, depending on the coastal region considered (Fig. 2d). L. hyperborea was stable in the Skagerrak and south-western Norway, as climate change and eutrophication had only minor effects in outer coastal areas and no grazing from sea urchins has been taking place in these areas (Rinde et al. 2014; Norderhaug et al. 2015a). However, in mid and northern Norway the kelp forests decreased dramatically from 1970 to 1990 due to sea urchin grazing. From 1990-2011 the kelp recovered in mid Norway due to kelp regrowth after grazing (Norderhaug and Christie 2009; Rinde et al. 2014), even though urchin barrens still remain in otherwise recovered areas, in particular in the fjord and sheltered areas (Rinde et al. 2014). In the outer wave exposed areas the L. hyperborea kelp forest was not grazed by sea urchins and shows a stable trend. The kelp stayed stable at a grazed state in northern Norway. Thus, for the whole period, 1970-2011, the kelp has been stable in Skagerrak and southwest Norway but has decreased in both mid and northern Norway, not fully recovering to reference conditions. The majority of experts from Norway state that the kelp forest extent is increasing (i.e. category A, Table 3). However, the maps (Fig. 2d) suggest that the kelp forest species dominating the Norwegian coast (Laminaria hyperborea) declined in spatial extent along most of the Norwegian coastline. This discrepancy is explained by the temporal scale at which the experts have responded compared to the temporal scale for which the kelp distribution has been assessed in Fig. 2b. The L. hyperborea kelp forests have in many areas recovered from grazing by sea urchins. However, many areas are still completely grazed down (northern Norway) and even in recovered areas, patches of sea urchin dominated areas are still found. The map (Fig. 2d) therefore still has areas classified as decreased, even though there has been a recovery in most of the areas.

At the island of Helgoland in the North Sea L. hyperborea significantly increased its biomass and expanded its depth distribution between 1968 and 2005 at the expense of $L$. digitata and S. latissima (Pehlke and Bartsch 2008).

The little data available on trends in the rest of the European coast show small-scale variations in the trend direction with reported trends of expansion, stability or decrease in central Europe and isolated reports of decrease or extinction in populations of the Iberian 
Peninsula (see Martinez et al. 2015; Assis et al. 2016; Piñeiro-Corbeira et al. 2016), as well shifting of several populations to inhabit deeper habitats (Martinez et al. 2015).

Laminaria ochroleuca is found between the Strait of Messina in Italy (Ribera et al. 1992) and the Isla de Alboran (Conde and Flores Moya 2000) to Devon in the UK (Guiry 2012) (Fig. 3c). Temporal trends are available mainly for the Bay of Biscay showing a general reduction of the populations abundance. This trend was also registered in some isolated populations of the northern coast of France and south of the UK, while others have increased or stabilized their abundance over the last years (Fig. 3c).

Laminaria rodriguezii is confined to very deep areas of the Mediterranean Sea (Balearic and Alboran Island) and of the Gorringe Bank where this species has been repeatedly reported in several locations over the last decade (Fig. 3d). The few available temporal data from the Adriatic sea, obtained in surveys undertaken between 1948-1949 and 2002, showed that this species has become exceptionally rare or has completely disappeared from this area. Repeated surveys in 2010 showed no recovery of the species. These losses have been linked to intensive trawling (Zuljevic et al. 2011). In other areas of France, Italy and Tunisia the species records date back mainly to the 1960-1970s, while in this work recent accessible information on the status of these populations was not found.

Saccorhiza polyschides forests are distributed along the European coastline from the Strait of Messina (Ribera et al. 1992), to the Isla de Alborán (Conde and Flores Moya 2000) up to Mid Norway (Brattegard and Holthe 2001). A trend of decrease in S. polyschides abundance is indicated in this study for southern Europe and for some isolated
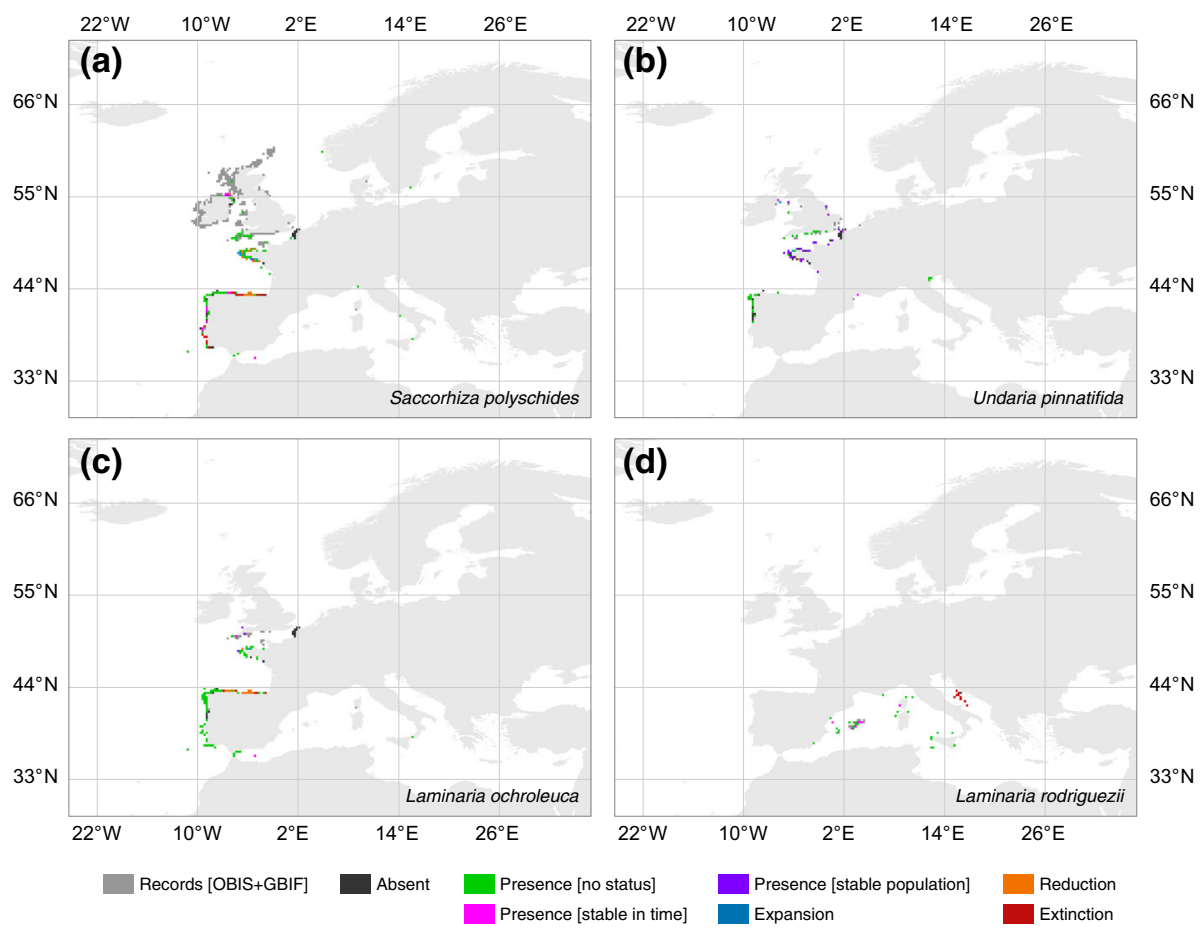

Fig. 3 Map showing the results of the mapping exercise for the following kelp species: a Saccorhiza polyschides; b Undaria pinnatifida; $\mathbf{c}$ Laminaria ochroleuca; $\mathbf{d}$ Laminaria rodriguezii 
localities of the northern coast of France. In the northern Iberian Peninsula (with exception of the Bay of Biscay) this species seems to have maintained stable distribution over the last years but no data are available on trends in this area (Fig. 3a). South of the S. polyschides forests in the Iberian Peninsula, two sharp declines in density were observed along the coast by comparing records from 1960 to nowadays, the first below latitude $41^{\circ} \mathrm{N}$ (mean density $<10$ individuals $\mathrm{m}^{-2}$ ) followed by an even sparser region in the south (mean density $<5$ individuals $\mathrm{m}^{-2}$ ), below latitude $38^{\circ} \mathrm{N}$ (Assis et al. 2013). In this southernmost region, temporal data of abundance indicated strong demographic regressions, local extinctions, and extinctions followed by recolonizations that were confirmed by genetic analyses, since bottleneck signs were retrieved for three of these southernmost populations (Assis et al. 2013). Interestingly, the detection of bottleneck signs from genetic data was only possible a few generations after such demographic changes; and illustrates that this regression is a contemporary phenomenon now occurring in the studied region. There was no information on the status and trends in the Norwegian population of this species. In France, the distribution of this species appears more or less stable even if in some areas a reduction in abundance has been recorded. In a few localities an expansion trend was referred for this species, which could be favoured by some local decrease of L. digitata, due to harvesting. No updated dataset was available for the Mediterranean, although the presence of $S$. polyschides is known in this area. The only detailed record for the species from the Strait of Messina, where data collected in 1998-2000 were compared with past maps by Mojo and Buta 1971, reported a marked contraction in the distribution of the species along the coast of Calabria, between Villa S. Giovanni and Capo Paci (Zampino and Martino 2000). Local experts contacted by the authors (D. Serio) suggested that nowadays the species may be no longer present in the Strait of Messina.

Undaria pinnatifida has been introduced to the Mediterranean Sea from Asia in 1971 (Boudouresque et al. 1985). It was intentionally introduced in several areas in Europe (e.g. Brittany, Northern France) for cultivation in the late 1970s-early 1980s because it is an edible seaweed. It rapidly escaped into the wild from farms (e.g. Floc'h et al. 1996; Voisin et al. 2005) and is currently distributed along several stretches of coast, from Italy to Britain (Stegenga et al. 2007; Araújo et al. 2009; Grulois et al. 2011; Sfriso and Facca 2013; Veiga et al. 2014). The little data available for $U$. pinnatifida, mainly presence/ absence records, show that this non-native species is widespread from the northwestern Iberian Peninsula to the English Channel, in particular along the northern coast of France (Fig. 3b). In the north, there is however a single record of $U$. pinnatifida, in Northern Ireland where the species recently established (2012). However, this distribution is likely explained by a higher number of surveys in some areas and may not reflect its present-day distribution. In Brittany, monitoring and research studies documented on-going local expansion (e.g. Bay of Morlaix, Viard pers. comm.). U. pinnatifida is mostly reported in artificial habitat such as marinas in the south of the UK, with far fewer records in natural habitat, e.g. in Devon, southwest England (MarClim dataset) and in Britain (Viard pers. comm).

\section{Discussion}

This study shows that large-scale spatial trends for any of the native kelp forest species in Europe are difficult to identify as a result of one or more of the following reasons: i) the lack of available long-term quantitative datasets in large parts of the geographical 
distribution range of kelp species in Europe; ii) the occurrence of small scale spatial variability with some species increasing in parts of their geographical distribution but decreasing in other areas, in some cases few kms apart from each other. Additionally, contrasting trends for the same species were documented at different depths or due to local small-scale variations in e.g. wave exposure.

Nevertheless, from the data available, a dominant decreasing tendency in kelp forest distribution and abundance was found across Europe. The same pattern was found in a recent global assessment of kelp forest changes that included a few datasets from Europe (Sousa-Pinto pers. com.). An exception is the increase of some populations in some localities of France, Germany, Norway and Svalbard. Uncertainties also occur when attempting to characterize quantitatively and accurately the (documented) European expansion of the non-native kelp $U$. pinnatifida. New data based on long term monitoring programs designed to allow quantitative comparisons are required to confirm these trends since data presented in this study comprised different temporal periods and for many areas are based in qualitative data which fail to detect possible decreases in populations abundances. This is a general limitation identified also in other studies (Yesson et al. 2015) when attempting to detect global patterns at the European scale.

In remote places like the Arctic the information on kelp forest stability is scarce although some areas might be particularly subjected to change in the near future by warming and the concomitant sea-ice decrease (e.g. Johannessen et al. 2004; Nordli et al. 2014; Pavlov et al. 2013) and productivity increase of kelp forests is foreseen (KrauseJensen and Duarte 2014). Consequently, continuous monitoring programs are needed here. An example of this situation is the recent biomass increase of kelps in Kongsfjorden (western Spitsbergen, Svalbard) which was mostly due to an increase of L. digitata at shallow depths possibly as a consequence of reduced sea ice formation and physical disturbance and increasing number of ice-free days (Bartsch et al. 2016). The concomitant trend in a decline of the lower depth extension of several kelp species was attributed to a decrease in the annual underwater irradiance budget due to increased sedimentation (Bartsch et al. 2016).

In northern European regions like Norway, grazing by sea urchins is regarded as the most important stressor affecting kelp species, specially in the northern and mid part of Norway where recovery of kelp forests are in progress after the intensive grazing period between 1970-1990s (Lang and Mann 1976; Norderhaug and Christie 2009). Sivertsen (1997) estimated that $2000 \mathrm{~km}$ of the kelp-rich coastline was grazed by sea urchins, implying a loss of about 20 million tonnes of L. hyperborea kelp forest in Norway (Gundersen et al. 2010). Records of the sea urchin $S$. droebachiensis sea urchin densities within this area are given by Sivertsen (1997), Sivertsen and Hopkins (1995) and Skadsheim et al. (1995). The $L$. hyperborea kelp recovery in the southern part of the grazed area (i.e. mid Norway) has expanded northwards since the 1990s due to reduced sea urchin populations (Norderhaug and Christie 2009; Rinde et al. 2014). The reduction in sea urchins is linked directly to warming by a resulting reduction in sea urchin recruitment (Fagerli et al. 2013; Rinde et al. 2014) and indirectly through increased predation from crabs expanding their range (Fagerli et al. 2014). Other important stressors for L. hyperborea in this area are storms and commercial kelp harvesting. At the island of Helgoland, the increase in biomass and depth distribution of L. hyperborea was probably related to an increased light penetration due to changed water masses in recent decades (Wiltshire et al. 2008).

Most of the S. latissima kelp forests along the inner and sheltered parts of the Norwegian Skagerrak and parts of the south-western coast of Norway have been replaced by communities of opportunistic and ephemeral filamentous algae, resulting in a much lower 
species richness and abundance (Christie et al. 2009). A reduction in the distribution of this species has also been observed in Sweden, Denmark (Moy et al. 2008) and Germany (Pehlke and Bartsch 2008). Reasons for these dramatic changes have not been unequivocally identified, even though increased sea temperature, and concentrations of nutrients and particles are probably important factors (Moy and Christie 2012) but increased sedimentation and fouling has also been discussed to hinder recovery (Andersen et al. 2013). Also, a reduction in animal grazing on the filamentous algae competing with S. latissima, have been suggested as an important driver of the distribution of this species (e.g. Rueness and Fredriksen 1991; Valiela et al. 1997; Schramm 1999; Schiel and Foster 2006; Moy and Stålnacke 2007; Moksnes et al. 2008).

In the North and Baltic Sea data for L. digitata show a reduction in abundance and depth occurrence. The reasons for this reduction are unknown but may be a consequence of competition between species, namely caused by the expansion of $L$. hyperborea. Recently it was shown that the reproductive efficiency of the infralittoral population of L. digitata was negatively affected in summer conditions, and that this upper population may become eradicated intermittently after warm summers (Bartsch et al. 2013). In the Baltic, where $L$. digitata reaches its salinity limits, the recorded changes might be due to hydrological reasons.

In central Europe trends of most abundant kelp species vary according to species identity and geographical area.

Kelp trends around the UK were not assessed and only presence data were mapped. As for other European regions, kelp forests in the UK have been understudied over the last decades (Smale et al. 2013). The few studies available suggest that changes in the abundances of some kelp species might be occurring (Simkanin et al. 2005; Smale and Vance 2015; Smale et al. 2015; Yesson et al. 2015). A meta-analysis of historical records of brown macroalgae around the UK coastline found regional differences in abundance trends, with declines in the southern region, but no change or increases in central and northern regions of the UK (Yesson et al. 2015). Interestingly, seasonal differences in correlative relationships between kelp abundance and sea surface temperature were found: $L$. digitata and L. hyperborea showed positive correlations with summer temperature, but negative responses to warmer winter temperatures, thought to be due to different thermal conditions required for initiation and success of different life history stages ( $\underline{\text { Yesson et al. }}$ 2015; Assis et al. 2016).

Around the coast of France kelp abundances vary independently of the latitude. Brittany constitutes a mosaic of contrasting conditions, with the western and north-western regions being colder and less affected by climate change than the other three regions (DerrienCourtel et al. 2013; Gallon et al. 2014). The highest abundance of L. digitata and L. hyperborea is found in these two colder regions and correlates with higher genetic diversity, although a trend of decrease in these specieś abundance is revealed for some parts of the central European coasts for small isolated marginal populations (Billot et al. 2003; Valero et al. 2011; Couceiro et al. 2013; Robuchon et al. 2014). Signs of maladaptive response (alteration of meiosis) of $L$. digitata at its southern edge of its distribution (Southern Brittany) became apparent where genetic diversity has declined (Oppliger et al. 2014). Such a response means that this European kelp species is at risk of local extinction as predicted by Ecological Niche Models under global change scenarios (Raybaud et al. 2013; Assis et al. 2016). However, some acclimation, e.g. for more turbid water, has been reported (Delebecq et al. 2013). These decreases could be compensated locally by $S$. polyschides, that has already been reported to be an opportunistic species (Peteiro et al. 2006; Engelen et al. 2011). Engelen et al. (2011) showed that recolonization is faster for $S$. 
polyschides than $L$. digitata during the first year after experimental eradication in Brittany although $L$. digitata populations seem to outcompete $S$. polyschides after this period. In the specific case of $U$. pinnatifida, most of its present-day distribution in France seems to be explained by past farming activities of this seaweed which were the triggers for the initial establishment of populations in natural habitats then human-made infrastructures (marinas, seawalls) were important pathways for its spread (Voisin et al. 2005; Grulois et al. 2011). Aquaculture is also the primary vector of its introduction in Spain (Báez et al. 2010). Local expansion has been documented in Brittany, as in UK and Ireland (Heiser et al. 2014; Minchin and Nunn 2014; Arnold et al. 2016), in the last two decades whereas Mediterranean populations decline, probably as a response to warm temperature and a predicted expansion was not confirmed by field data in Portugal (Veiga et al. 2014). There is thus a qualitative invasive trend (i.e. expansion) of U. pinnatifida in Northern Europe. However, this expansion cannot be ascertained with accuracy in the absence of quantitative data. Several years ago, Strayer et al. (2006) emphasized the importance of repeated surveys and monitoring programs for understanding the long-term effects of non-native species but such surveys are very rarely supported by funding bodies.

In the Iberian Peninsula quantitative data are scarce for most of the species but in the southwest of Portugal and along the Bay of Biscay shores, a trend of decreasing abundance was verified for $S$. polyschides, L. hyperborea and L. ochroleuca. These results are in accordance with recent publications reporting on range contractions and/or changes in abundance in recent years, at the southern and eastern distributional ranges of these species (Fernández 2011; Díez et al. 2012; Assis et al. 2013, 2016; Voerman et al. 2013; Martinez et al. 2015). Global warming was the main driver of kelps change identified for this region by experts which is in agreement with recent studies relating the recent retreat in kelp distribution with the global trend of increasing sea surface temperature (Díez et al. 2012; Voerman et al. 2013; Sousa-Pinto pers. com.) and with modelling approaches (Müller et al. 2009; Bartsch et al. 2012). It is suggested that recent changes of population structure and dynamics (Fernández 2011) or local extinctions at the southern edge of kelp distribution, which was supported by genetic data (Assis et al. 2013), might also be related to responses to global warming. Nevertheless, the scarce information about the global distribution of kelp species may preclude a full understanding about the putative consequences of recent climate changes. For instance, cryptic offshore regions like marine seamounts may provide suitable conditions for kelp species, away from the surface warming trends. This may provide seed-banks for other populations that would otherwise become extinct (Assis et al. 2015).

Differing physiological responses to increasing temperatures have been demonstrated for S. polyschides and L. ochroleuca and many other kelp species suggesting that responses to increasing sea surface temperature might be species specific (Pereira et al. 2011; Biskup et al. 2014). However, because the kelp life cycle alternates from microscopic gametophyte to macroscopic sporophyte stages (Matson and Edwards 2007), a full understanding of their responses to increasing temperatures can only be achieved when all life stages have been investigated (Schiel and Foster 2006).

The absence of conservation programs reported by experts in most of the southern Atlantic European coast is a matter of concern. Although such programs are not able to reverse the current trend of decrease of kelp forests, if it is related to global warming, they could target the reduction of other potential stressors identified as relevant for this area by experts, such as water turbidity or eutrophication. Conservation approaches such as recovery programs for previously commercially exploited top predators and pollution management were already successful in improving the conditions of kelps in some parts of 
the world, (e.g. West coast of Vancouver Island, Southern California Bight) (Sousa-Pinto pers. com.). Of particular importance would be the establishment of monitoring programs targeting the species with an invasive behavior or with identified decreasing trends to which current and past geographical distribution and abundances are mostly unknown.

In general the Mediterranean Sea was extremely data poor for kelp biomass and species, possibly because it mostly houses deep water populations which are difficult to access. Most of the available records of the presence of kelp species are from past records from the 1960 s and $70 \mathrm{~s}$, while nowadays information is virtually nil even for shallow water species such as $S$. polyschides. Recent comparison with past records for S. polyschides (Malaga: from 1953 to 1983, Granada: 1976; Izquierdo et al. 1995) showed that they became extinct here (Assis pers. com.). A warming trend has also been reported for these waters, as one with the highest increasing rates throughout the world's oceans (Belkin 2009). Similarly, the few available data for L. rodriguezii from the Adriatic Sea and for L. ochroleuca and $S$. polyschides from the Strait of Messina suggest a very severe reduction (up to possible local extinction). The causes of this reduction are not well known, but one of the most likely drivers of loss includes trawling (Zuljevic et al. 2011).

\section{Conclusion}

Major knowledge gaps were identified and the very restricted availability of quantitative data to precisely assess the current status and trends of kelp forests became very obvious. The expansion trend of a non-native kelp at the European scale with potential ecological and economic impacts in particular on fisheries could also not be adequately assessed. The results underline a crucial need for setting up more coordinated monitoring programs relying on harmonized protocols as already pointed out by Merzouk and Johnson (2011) and Smale et al. (2013). This present study also highlights the difficulties of conducting an expert consultation exercise when there is the requirement to involve a large number of experts covering wide geographical areas. After a successful first assemblage of knowledge through questionnaires that resulted in a first picture of the status and trends of kelp forests in Europe in form of a report (Schindler et al. 2013) the decision to increase the accuracy and coverage through data mining turned into a difficult and time consuming exercise. This was particularly difficult when integrating data from countries with few experts working on kelp forests (like Denmark, Sweden, Greenland, Iceland) or when experts were not willing to contribute. As a consequence in some places the results did not reflect the actual knowledge and available expertise (e.g. UK/Ireland). In all cases the time availability of experts acted as a strong limiting factor.

Nevertheless, this paper represents the first large successful step towards the creation of a European scale data set on the distribution and trends of kelp ecosystems. In a scenario of funding availability, this database will facilitate the identification of priority study areas to where data are missing or need higher sampling effort. This could be done in support of the Marine Strategy/Water Framework Directives, in marine protected areas, and as requirements for exploitation of kelp. For some areas that were subject to severe deforestation due to e.g sea urchin grazing, afforestation with local species could also increase the recovery of this important ecosystem.

Acknowledgments We would like to thank to the following persons or entities: (1) Lise Tveiten (NIVA) and Frithjof Moy (Institute of Marine Research, IMR), who for many years have sampled data on kelp forest ecology and distribution along the Norwegian coast; (2) The financial partners of the two monitoring 
programs "the Brittany REBENT" and the "European Water Framework Directive" for making it possible to obtain valuable data: the Brittany Region, the European Regional Development Fund, the Loire-Brittany Water Agency, the ONEMA, Ifremer, the MNHN and the Estuaires Loire Vilaine association; (3) Elodie Catherine, François-Xavier Decaris, René Derrien, Marie Mercier-Pécard, Nicolas Mercier and Thomas Abiven Annie Castric-Fey, Annie Girard-Descatoire, Marie-Thérèse L'Hardy-Halos (MNHN Station de Biologie Marine de Concarneau) who have, for many years, also contributed to French data on kelp forest ecology and distribution; (4) The marine operation department (Service Mer et Observation) of the Station Biologique de Roscoff and the natural marine park Parc Naturel Marin d'Iroise; (5) The MarClim project at the Marine Biological Association of the UK that has maintained long-term studies of kelps in the UK thanks to funding from Natural England and Natural Resources Wales; (6) Rolf Karez and the State Agency for Agriculture, Environment and Rural Areas, Lower Saxony, Germany who have a regular kelp monitoring program in the German North Sea with Philipp Schubert, being the main responsible diving expert; (7) Christian Wiencke (Alfred-Wegener-Institute, Bremerhaven, Germany) who established the recent quantitative diving study at Kongsfjorden, Spitsbergen, where the sampling was performed with major help from Max Schwanitz and Martin Paar; (8) Annalisa Falace who reviewed the data for the Adriatic Sea; (9) The Portuguese Foundation for Science and Technology (projects of Ester Serrao: EXCL/AAG-GLO/0661/2012 and PTDC/MAR-EST/6053/2014) and postdoctoral fellowship to JA (SFRH/BPD/111003/2015) and RA (SFRH/BPD/75843/2011); (10) The project TETRIS (PRIN 2010-2011, MIUR) for support to LA and EMS. This work was funded by the European Commission under FP7 as the coordination action KNEU"Developing a Knowledge Network for EUropean expertise on biodiversity and ecosystem services to inform policy making economic sectors" (Grant No. 265299).

\section{References}

Airoldi L (2003) The effects of sedimentation on rocky coast assemblages. Oceanogr Mar Biol Annu Rev 41:161-236

Airoldi L, Beck MW (2007) Loss, status and trends for coastal marine habitats of Europe. Oceanogr Mar Biol Annu Rev 45:345-405

Andersen GS, Pedersen MF, Nielsen SL (2013) Temperature acclimation and heat tolerance of photosynthesis in Norwegian Saccharina latissima (Laminariales, Phaeophyceae). J Phycol 49:689-700

Araújo R, Bárbara I, Tibaldo M, Berecibar E, Diaz-Tapia P, Pereira R, Santos R, Sousa-Pinto I (2009) Checklist of benthic marine algae and cyanobacteria of northern Portugal. Bot Mar 52:24-46

Ardré F (1970) Contribution à l'étude des algues marines du Portugal. I. La flore. Port. Acta Biol. Ser. B, Sist. B. 423

Arnold M, Teagle H, Brown MP, Smale DA (2016) The structure of biogenic habitat and epibiotic assemblages associated with the global invasive kelp Undaria pinnatifida in comparison to native macroalgae. Biol Invasions. doi:10.1007/s10530-015-1037-6

Assis J, Tavares D, Tavares J, Cunha A, Alberto F et al (2009) Findkelp, a GIS-based community participation project to asses portuguese kelp conservation status. J Coast Res 3:1469-1473

Assis J, Coelho NC, Alberto F, Valero M, Raimondi P, Reed D, Serrão EA (2013) High and distinct rangeedge genetic diversity despite Local Bottlenecks. PLoS ONE 8:e68646

Assis J, Coelho NC, Lamy T, Valero M, Alberto F, Serrão EA (2015) Deep reefs are climatic refugia for genetic diversity of marine forests. J Biogeogr 43:833-844

Assis J, Lucas AV, Bárbara I, Serrão EA (2016) Future climate change is predicted to shift long-term persistence zones in the cold-temperate kelp Laminaria hyperborea. Mar Environ Res doi:10.1016/j. marenvres.2015.11.005

Báez J, Olivero J, Peteiro C, Ferri-Yáñez F, Garcia-Soto C, Real R (2010) Macro-environmental modelling of the current distribution of Undaria pinnatifida (Laminariales, Ochrophyta) in northern Iberia. Biol Invasions 12:2131-2139

Bárbara I (1994) Las comunidades de algas bentónicas marinas en la bahía de La Coruña y ría del Burgo. Dissertation, Universidad de Santiago de Compostela

Bárbara I, Cremades J (1996) Seaweeds of the Ria de A Coruna (NW Iberian Peninsula, Spain). Bot Mar 39: 371-388

Bartsch I, Wiencke C, Laepple T (2012) Global seaweed biogeography under a changing climate: the prospected effects of temperature. In: Wiencke C, Bischof K (eds) Seaweed biology: novel insights into ecophysiology, ecology and utilization. Springer, Heidelberg, pp 383-406

Bartsch I, Vogt J, Pehlke C, Hanelt D (2013) Prevailing sea surface temperatures inhibit summer reproduction of the kelp Laminaria digitata at Helgoland (North Sea). J Phycol 49:1061-1071 
Bartsch I, Paar M, Fredriksen S, Schwanitz M, Daniel C, Hop H, Wiencke C (2016) Changes in biomass and depth distribution in Kongsfjorden (Spitsbergen) between 1996-1998 and 2012-2014 reflect Arctic warming. Polar Biol. doi:10.1007/s00300-015-1870-1

Bekkby T, Moy F (2011) Developing spatial models of sugar kelp (Saccharina latissima) potential distribution under natural conditions and areas of its disappearance in Skagerrak. Estuar Coast Shelf Sci 95:477-483

Bekkby T, Rinde E, Erikstad L, Bakkestuen V (2009) Spatial predictive distribution modelling of the kelp species Laminaria hyperborea. ICES J Mar Sci 66:2106-2115

Belkin IM (2009) Rapid warming of large marine ecosystems. Prog Oceanogr 81:207-213

Bertocci I, Araújo R, Oliveira P, Sousa-Pinto I (2015) Potential effects of kelp species on local fisheries. J App Ecol 52:1216-1226

Bescansa Casares F (1948) Herborizaciones algológicas en La Coruña. Nigrán y Bayona, La Coruña

Billot C, Boury S, Benet H, Kloareg B (1999) Development of RAPD markers for parentage analysis in Laminaria digitata. Bot Mar 42:307-314

Billot C, Engel CR, Rousvoal S, Kloareg B, Valero M (2003) Current patterns, habitat discontinuities and population genetic structure: the case of the kelp Laminaria digitata in the English Channel. Mar EcolProg Ser 253:111-121

Biskup S, Bertocci I, Arenas F, Tuya F (2014) Functional responses of juvenile kelps, Laminaria ochroleuca and Saccorhiza polyschides, to increasing temperatures. Aquat Bot 113:117-122

Boudouresque CF, Perret M (1977) Inventaire de la Flore Marine de Corse (Méditeranée): Rhodophyceae, Phaeophyceae, Chlorophyceae. Ganter Verlag, Bryopsidophyceae

Boudouresque CF, Gerbal F, Knoepffler-Peguy M (1985) L'algue japonaise Undaria pinnatifida (Phaeophyceae, Laminariales) en Méditerranée. Phycologia 24:364-366

Brattegard T, Holthe T (2001) Distribution of marine, benthic macro-organisms in Norway. A tabulated catalogue. Preliminary Edition. Research Report No. 1997-1

Breuer G, Schramm W (1988) Changes in macroalgal vegetation in the Kiel bight (Western Baktic Sea) during the past 20 years, Kieler Meeresf. Sonderh 6:241-255

Brodie JF, Aslan CE, Rogers HS, Redford KH, Maron JL, Bronsteire JL, Groves CR (2014) Secondary extinctions of biodiversity. Trends Ecol Evol 29:664-672

Castric A (1996) Nouvelles de 1 'ADMS ${ }^{\circ} 19$

Castric-Fey A, Girard-Descatoire A, Hardy-Halos M-T, Derrien-Courtel S (2001) La vie sous-marine en Bretagne-Découverte des fonds rocheux. Les Cahiers Naturalistes de Bretagne n³, Conseil Régional de Bretagne, Biotope édit

Christie H, Fredriksen S, Rinde E (1998) Regrowth of kelp and colonization of epiphyte and fauna community after kelp trawling at the coast of Norway. Hydrobiologia 375(376):49-58

Christie H, Norderhaug KM, Fredriksen S (2009) Macrophytes as habitat for fauna. Mar Ecol Prog Ser 396:221-233

Chung IK, Oak JH, Lee JA, Shin JA, Kim JG, Park KS (2013) Installing kelp forests/seaweed beds for mitigation and adaptation against global warming: Korean Project Overview. ICES J Mar Sci 70:1038-1044

Conde F, Flores Moya A (2000) Nuevas adiciones al conocimiento de las macroalgas marinas de la isla de Alborán (Mediterráneo Occidental). Acta Botanica Malacitana 25:180-184

Costanza R, d'Arge R, de Groot R, Farber S, Grasso M, Hannon B, Limburg K, Naeem S, O’Neill RV, Paruelo J, Raskin RG, Sutton P, van den Belt M (1997) The value of the world's ecosystem services and natural capital. Nature 387:253-260

Couceiro L, Robuchon M, Destombe C, Valero M (2013) Management and conservation of the kelp species Laminaria digitata: using genetic tools to explore the potential exporting role of the MPA "Parc naturel marin d'Iroise. Aquat Living Resour 26:197-205

Cremades UJ, Freire OG, Peteiro CG (2006) Biología, distribución e integración del alga alóctona Undaria pinnatifida (Laminariales, Phaeophyta) en las comunidades bentónicas de las costas de Galicia (N.O. Península Ibérica). Anales Jardin Botanico Madrid 63:169-187

Delebecq G, Davoult D, Menu D, Janquin MA, Dauvin JC, Gevaert F (2013) Influence of local environmental conditions on the seasonal acclimation process and the daily integrated production rates of Laminaria digitata (Phaeophyta) in the English Channel. Mar Biol 160:503-517

Derrien-Courtel S (2008) L'étude des peuplements subtidaux rocheux (flore et faune) du littoral breton permet-elle de contribuer à l'évaluation de la qualité écologique du littoral et d'en mesurer les changements dans le temps ? Dissertation. Muséum National d'Histoire Naturelle

Derrien-Courtel S, Catherine E. (2012) Programme REBENT Bretagne-Suivi stationnel des roches subtidales, année 2011 
Derrien-Courtel S, Le Gal A, Grall J (2013) Regional-scale analysis of subtidal rocky shore community. Helgoland Mar Res 1-16

Dicks LV et al (2016) Enhancing natural pest control as an ecosystem service: a summary and assessment of selected evidence for agronomists and agricultural policy makers. Biodivers Conserv. doi:10.1007/ s10531-016-1133-7

Di Geronimo (1987) Bionomie des peuplements bentiques des substrats meubles et rocheux Plio-Quaternaires du Detroit de Messine. Doc. et Trav. IGAL, Paris 11: 153-169

Díez I, Muguerza N, Santolaria A, Ganzedo U, Gorostiaga JM (2012) Seaweed assemblage changes in the eastern Cantabrian Sea and their potential relationship to climate change. Estuar Coast Shelf S 99:108-120

Dizerbo AH, Herpe É (2007) Checklist and repartition of seaweeds on the French coasts of the Channel and of the Atlantic ocean, including the British Channel islands. Éd. Anaximandre

Drew EA (1974) An ecological study of Laminaria ochroleuca Pyl. growing below 50 metres in the Straits of Messina. J Exp Mar Biol Ecol 15:11-24

Duggins DO, Simenstad CA, Estes JA (1989) Magnification of secondary production by kelp detritus in coastal marine ecosystems. Science 245:170-173

Ellertsdóttir E, Peters AF (1997) High prevalence of infection by endophytic brown algae in populations of Laminaria spp. (Phaeophyceae). Mar Ecol Prog Ser 146:135-143

Engelen AH, Lévèque L, Destombe C, Valero M (2011) Spatial and temporal patterns of recovery of low intertidal Laminaria digitata after experimental spring and autumn removal. Cah Biol Mar 52:441-453

Fagerli CW, Norderhaug KM, Christie HC (2013) Lack of sea urchin settlement may explain kelp forest recovery in overgrazed areas in Norway. Mar Ecol Prog Ser 488:119-132

Fagerli CW, Norderhaug KM, Christie H, Pedersen MF, Fredriksen S (2014) Predators of the destructive sea urchin grazer (Strongylocentrotus droebachiensis) on the Norwegian coast. Mar Ecol Prog Ser 502:207-218

Fernández C (2011) The retreat of large brown seaweeds on the north coast of Spain: the case of Saccorhiza polyschides. Eur J Phycol 46:352-360

Fischer-Piette E, Seoane-Camba J (1962) Écologie de la riatype: la Ria del Barquero. Bulletin de l'Institut Oceanogra-phique 1244:1-36

Fischer-Piette E, Seoane-Camba J (1963) Examen écologique della ría de Camariñas. Bulletin de l'Institut Oceanographique 61:1-38

Floc'h JY, Pajot R, Mouret V (1996) Undaria pinnatifida (Laminariales, phaeophyta) 12 years after its introduction into the Atlantic ocean. Hydrobiologia 326(327):217-222

Fredj G (1972) Stockage et exploitation des données en écologie marine. A-Un fichier sur ordinateur des invertébres macrobenthiques. Mém. Inst. Oceanogr. Monaco 4

Fredriksen S, Bartsch I, Wiencke C (2014) New additions to the benthic marine flora of Kongsfjorden, western Svalbard and comparison between 1996/98 and 2012/13. Bot Mar 54: 203-216

Gallardo T, Margalet JL (1992) Aportación al conocimiento de la flora bentónica marina de la ría de Foz (Lugo, España). Actes del Simposi Internacional de Botànica Pius Font i Quer 1: 119

Gallon RK, Robuchon M, Leroy B, Le Gall L, Valero M, Feunteun E (2014) Twenty years of observed and predicted changes in subtidal red seaweed assemblages along a biogeographical transition zone: inferring potential causes from environmental data. J Biogeogr 41:2293-2306

Gevaert F (2001) Importance des facteurs de l'environnement et du phénomène de photoinhibition sur la production des grandes algues marines. Dissertation. Université Lille1

Gevaert F, Janquin MA, Davoult D (2008) Biometrics in Laminaria digitata: a useful tool to assess biomass, carbon and nitrogen contentes. J Sea Res 60:215-219

Giaccone G (1967) Popolamenti a Laminaria rodriguezii Bornet nel Banco Apollo dell'Isola di Ustica (Mar Tirreno). Nuova Thalassia 3:1-9

Giaccone G (1970) Raccolte di fitobenthos sulla banchina continentale italiana. Giornale Botanico Italiano 103:485-514

Giaccone G, Giaccone T, Catra M (2009) Association with Laminaria rodriguezii on a detritic bottom and on rocks: Cystoseiretum zosteroidis Giaccone 1973 subass. Laminarietosum rodriguezii Giaccone 1973. In: Priority habitats according to the SPA/BIO protocol (Barcelona Convention) present in Italy. Identification sheets. 16: 204-208

Gili C, Anadón R, Carbonell J, Olivella I, Ros J (1982) Comunidades bentónicas submarinas del litoral de Lugo. I. Resultados preliminares. Actas I Simposio Ibérico de Estudios del Bentos Marino 711-749

Girard-Descatoire A, Castric-Fey A, L’Hardy-Halos MT (1997) Inventaire de la faune et de la flore sur les fonds rocheux de Saint-Malo et de Dinard. Report for Direction Régionale de l'Environnement Bretagne, Conseil Régional de Bretagne. Rennes 
Granja A, Cremades J, Bárbara I (1992) Catálogo de las algas bentónicas marinas de la Ría de Ferrol (Galicia, N.O. de la Península Ibérica) y consideraciones biogeográficas sobre su flora. Nova Acta Científica Compostelana (Bioloxía) 3:3-21

Grulois D (2010) Etude de la dispersion et du recrutement à différentes échelles spatiales chez Undaria pinnatifida, une macro-algue introduite le long des côtes bretonnes. UPMC

Grulois D, Leveque L, Viard F (2011) Mosaic genetic structure and sustainable establishment of the invasive kelp Undaria pinnatifida within a bay (Bay of St-Malo, Brittany). Cah Biol Mar 52:485-498

Guiry MD (2012) A catalogue of Irish seaweeds. A.R.G. Gantner Verlag K.G, Ruggell

Gulliksen B, Palerud R, Brattegard T, Sneli J (1999) Distribution of marine benthic macro-organisms at Svalbard (including Bear Island) and Jan Mayen Research Report for DN 1999-4. Directorate for Nature Management

Gundersen H, Christie HC, de Wit H, Norderhaug KM, Bekkby T, Walday M (2010) CO2 uptake in marine habitats-an investigation. NIVA report 3070-2012

Gundersen H, Bekkby T, Christie H, Moy FE, Tveiten LA (2012) Development of an indicator for sugar kelp (Saccharina latissima) for the Norwegian Nature Index-modeling reference condition for area distribution. NIVA report 6438-2012

Hamel G (1928) Les algues de Vigo. Revue Algologie 4:81-95

Heiser S, Hall-Spencer JM, Hiscock K (2014) Assessing the extent of establishment of Undaria pinnatifida in Plymouth Sound Special Area of Conservation, UK. Mar Biod Rec 7:e93

Helmuth BT, Russell BD, Connnell S, Dong Y, Harley CDG, Lima FP, Sarà G, Williams GA, Mieszkowska $\mathrm{N}$ (2014) Climate profiling: making biological sense of long term averages in a changing world. Clim Change Rev 1:6

Hill R, Bellgrove A, Macreadie PI, Petrou K, Beardall J, Steven A, Ralph PJ (2015) Can macroalgae contribute to blue carbon? An Australian perspective. Limnol Oceanogr 60:1689-1706

Hop H, Wiencke C, Vogele B, Kovaltchouk NA (2012) Species composition, zonation, and biomass of marine benthic macroalgae in Kongsfjorden, Svalbard. Bot Mar 55:399-414

Izquierdo Moreno JL (1998) Estudio biosistemático del género Laminaria Sect. Digitatae (Laminariales, Phaeophyceae) en las costas atlánticas de la Península Ibérica. Dissertation, Universidad Complutense

Izquierdo JL, Gallardo T, Pérez-Ruzafa I (1995) Mapas de distribución de algas marinas de la Península Ibérica e Islas Baleares. IX. Saccorhiza polyschides (Lightf.) Batt. y Chorda filum (L.) Stackh. (Laminariales, Fucophyceae). Botanica Complutensis 20:105-115

Jackson JBC, Kirby MX, Berger WH, Bjorndal KA, Botsford LW, Bourque BJ, Bradbury RH, Cooke R, Erlandson J, Estes JA et al (2001) Historical overfishing and the recent collapse of coastal ecosystems. Science 293:629-638

Johannessen OM, Bengtsson L, Miles MW, Kuzmina SI, Semenov VA, Alekseev GV, Nagurnyi AP, Zakharov VF, Bobylev LP, Pettersson LH, Hasselmann K, Cattle HP (2004) Arctic climate change: observed and modelled temperature and sea-ice variability. Tellus 56A:328-341

John DM (1968) Studies on littoral and sublittoral ecosystems. Dissertation, University of Durham

Krause-Jensen D, Duarte CM (2014) Expansion of vegetated coastal ecosystems in the future. Front Mar Sci 1: Article 77

Krause-Jensen D, Marbà N, Olesen B, Sejr MK, Christensen PB, Rodrigues J, Renaud PE, Balsby TJS, Rysgaard S (2012) Seasonal ice cover as principal driver of spatial and temporal variation in depth extension and annual production of kelp in Greenland. Glob Change Biol 18:2981-2994

Krumhansl K, Scheibling R (2012) Production and fate of kelp detritus. Mar Ecol-Prog Ser 467:281-302

Lang C, Mann KH (1976) Changes in sea urchin populations after destruction of kelp beds. Mar Biol 36:321-326

Le Gal A, Derrien-Courtel S (2015) Quality Index of Subtidal Macroalgae (QISubMac), a suitable tool for ecological quality status assessment under the scope of the European Water Framework Directive. Mar Pollut Bull 101:334-348

Le Roux A (2008) Les espèces introduites dans le Morbihan. Pen Ar Bed 202

Leclerc J-C, Riera P, Leroux C, Lévêque L, Laurans M, Schall G, Davoult D (2013) Trophic significance of kelps in kelp communities in Brittany (France) inferred from isotopic comparisons. Mar Biol 160:3249-3258

Leleu K, Remy-Zephir B, Grace R, Costello MJ (2012) Mapping habitats in a marine reserve showed how a 30-year trophic cascade altered ecosystem structure. Biol Conserv 155:193-201

Livoreil B, Geijzendorffer IR, Pullin AS, Schindler S, Vandewalle M, Nesshöver C (2016) Biodiversity knowledge synthesis at the European scale: actors and steps. Biodivers Conserv. doi:10.1007/s10531016-1143-5

López Varela C (2000) Las comunidades infralitorales de Laminaria ocroleuca y Laminaria hyperborea (Laminariales, Phaeophyta) en Galicia. Dissertation, Universidad de A Coruña 
Lorentsen SH, Sjotun K, Gremillet D (2010) Multi-trophic consequences of kelp harvest. Biol Conserv 143:2054-2062

Lüning K (1969) Standing crop and leaf area index of the sublittoral Laminariaspecies near Helgoland. Int J Life Oceans Coast Waters 3:282-286

Lüning K (1970) Tauchuntersuchungen zur Vertikalverteilung der sublitoralen Helgoländer Algenvegetation. Helgolwiss Meeresunters 21:271-291

Mann KH (1973) Seaweeds: their productivity and strategy for growth. Science 182:975-981

Mann KH (2000) Ecology of coastal waters. With implications for management. Blackwell Science, Oxford

Marino G, Di Martino V, Giaccone G (1999) Diversità della flora marina nella Penisola Maddalena (Siracusa): cambiamento ventennale ed evoluzione. Bollettino dell'Accademia Gioenia di Scienze Naturali. 354:289-315

Martinez B, Afonso-Carrillo J, Anadón R, Araújo R, Arenas F et al (2015) Regresión de las algas marinas en la costa atlántica de la Península Ibérica y en las Islas Canarias por efecto del cambio climático. ALGAS, Boletín Informativo Sociedad Española Ficología 49:5-12

Matson PG, Edwards MS (2007) Effects of ocean temperature on the southern range limits of two understory kelps, Pterygophora californica and Eisenia arborea, at multiple life-stages. Mar Biol 151:1941-1949

Merzouk A, Johnson LE (2011) Kelp distribution in the northwest Atlantic Ocean under a changing climate. J Exp Mar Biol Ecol 400:90-98

Mieszkowska N, Kendall MA, Hawkins SJ, Leaper R, Williamson P, Hardman-Mountford NJ, Southward AJ (2006) Changes in the range of some common rocky shore species in Britain-a response to climate change? Hydrobiologia 555:241-251

Mieszkowska N, Sugden H, Firth L, Hawkins SJ (2014) The role of sustained observations in tracking impacts of environmental change on marine biodiversity and ecosystems. Philos Trans Roy Soc A 372:20130339

Minchin D, Nunn J (2014) The invasive brown alga Undaria pinnatifida (Harvey) Suringar, 1873 (Laminariales: Alariaceae), spreads northwards in Europe. Bioinvasions Rec 3:57-63

Miranda F (1931) Sobre las algas y Cianofíceas del Cantábrico especialmente de Gijón. Trabajos del Museo Nacional de Ciencias Naturales de Madrid 25:7-106

Miranda F (1934) Materiales para una flora marina de las rías bajas gallegas. Boletín de la Real Sociedad Española de Historia Natural 34:165-180

Mojo L, Buta G (1971) Osservazione dei fondali dello Stretto di Messina mediante TV subacquea. Accademia Peloritana dei Pericolanti 50:65-71

Moksnes PO, Gullstrom M, Tryman K, Baden S (2008) Trophic cascades in a temperate seagrass community. Oikos 117:763-777

Molinier R (1960) Étude des biocénoses marines du Cap Corse. Vegetatio 9:212-312

Mork M (1996) The effect of kelp in wave damping. Sarsia 80:323-327

Moy FE, Christie H (2012) Large-scale shift from sugar kelp (Saccharina latissima) to ephemeral algae along the south west coast of Norway. Mar Biol Res 8:309-321

Moy F, Stålnacke P (2007) Sugar Kelp Project: Analyses of climate and environmental data. NIVA report 5454-2007, Klif report TA 2279/2007

Moy F, Christie H, Steen H, Stålnacke P, Aksnes D, Alve E, Aure J, Bekkby T, Fredriksen S, Gitmark J, Hackett B, Magnusson J, Pengerud A, Sjøtun K, Sørensen K, Tveiten L, Øygarden L, Åsen P (2008) Final report from sugar the kelp monitoring project. SFT report TA-2467/2008

Moy F, Naustvoll LJ, Trannum HC, Norderhaug KM, Gitmark JK (2015) ØKOKYST—subporgram Skagerrak, 2014 report. Norwegian Environment Agency report M-334

Müller R, Laepple T, Bartsch I, Wiencke C (2009) Impact of oceanic warming on the distribution of seaweeds in polar and cold-temperate waters. Bot Mar 52:617-638

Neßhöver C, Vandewalle M, Wittmer H, Balian E, Carmen E et al (2016) The Network of Knowledge approach-improving the science and society dialogue on biodiversity and ecosystem services in Europe. Biodivers Conserv. doi:10.1007/s10531-016-1127-5

Norderhaug KM, Christie H (2009) Sea urchin grazing and kelp re-vegetation in the NE Atlantic. Mar Biol Res 5:515-528

Norderhaug KM, Christie H, Fosså JH, Fredriksen S (2005) Fish-macrofauna interactions in a kelp (Laminaria hyperborea) forest. J Mar Biol Ass UK 85:1279-1286

Norderhaug KM, Gundersen H, Pedersen A, Moy F, Green N, Walday M, Magnusson J, Gitmark J, Ledang AB, Bjerkeng B, Trannum H (2015a) Combined effects from climate variation and eutrophication on the diversity in hard bottom communities on the Skagerrak coast 1990-2010. Mar Ecol Prog Ser 530:29-46 
Norderhaug KM, Naustvoll LJ, Trannum HC, Gitmark JK, Fagerli CW, Kile MR, Tveiten L, Håvardstun J, Vedal J (2015b) ØKOKYST_-subprogram Rogaland. 2014 report. Norwegian Environment Agency report M-335

Nordli Ø, Przybylak R, Ogilvie AEJ, Isaksen K (2014) Long-term temperature trends and variability on Spitsbergen: the extended Svalbard Airport temperature series, 1898-2012. Polar Res 33:21349

Oppliger LV, Correa JA, Engelen AH, Tellier F, Vieira V, Faugeron S, Valero M, Gomez G, Destombe C (2012) Temperature effects on gametophyte life-history traits and geographic distribution of two cryptic kelp species. PLoS ONE 7:e39289

Oppliger LV, von Dassow P, Bouchemousse S, Robuchon M, Valero M, Correa JA, Mauger S, Destombe C (2014) Alteration of sexual reproduction and genetic diversity in the kelp species Laminaria digitata at the southern limit of its range. PLoS ONE 9:e102518

Otero-Schmitt J, Pérez Cirera JL (2002). Infralittoral benthic biocoenoses from Ria de Muros, Atlantic coast of northwest Spain. Bot Mar 45: 93-122

Paar M, Voronkov A, Hop H, Brey T, Bartsch I, Schwanitz M, Wiencke C, Lebreton B, Asmus R, Asmus H (2015) Temporal shift in biomass and production of macrozoobenthos in the macroalgal belt at Hansneset, Kongsfjorden, after 15 years. Polar Biol. doi:10.1007/s00300-015-1760-6

Pavlov AK, Tverberg V, Ivanov BV, Nilsen F, Falk-Petersen S, Granskog MA (2013) Warming of Atlantic water in two west Spitsbergen fjords over the last century (1912-2009). Polar Res 32:11206

Pedel L, Fabri MC (2011) Description et cartographie des biocénoses benthiques rencontrées au cours de la campagne MEDSEACAN (Aamp/Comex). Convention MEDDTL/Ifremer 11/1219231. Ifremer 1-103

Pehlke C, Bartsch I (2008) Changes in depth distribution and biomass of sublittoral seaweeds at Helgoland (North Sea) between 1970 and 2005. Clim Res 37:135-147

Pereira TR, Engelen AH, Pearson GA, Serrão EA, Destombe C, Valero M (2011) Temperature effects on the microscopic haploid stage development of Laminaria ochroleuca and Sacchoriza polyschides, kelps with contrasting life histories. Cah Biol Mar 52:395-403

Pérez-Cirera JL (1975) Notas sobre la vegetación ficológica bentónica de la Ría de Cedeira (NO. de España). Anales del Instituto Botánico A. J. Cavanilles 32:161-171

Pérez-Cirera JL (1976) Tipos de vegetación bentónica cormofítica litoral del Noroeste de España (Ría de Corme y Lage). Documents Phytosociologiques 15-18:87-122

Pérez-Cirera JL, Maldonado JL (1982) Principales tipos de vegetación bentónica y su zonación en el litoral comprendido entre las Rías de Camariñas y de Corme y Lage (Costa de Camelle, La Coruña). Collectanea Botanica 13:893-910

Peteiro C, Salinas JM, Freire Ó, Fuertes C (2006) Cultivation of the autoctonous seaweed Laminaria saccharina off the Galician coast (NW Spain): Production and features of the sporophytes for an annual and biennial harvest. Thalassas 22:45-53

Petes LE, Howard JF, Helmuth BS, Fly EK (2014) Science integration into US climate and ocean policy. Nat Clim Change 4:671-677

Pignatti A, Rizzi Longo L (1972) Raccolte di alghe bentoniche nelle acque dell'Archipelago Toscano. Atti del Reale Istituto Veneto di Scienze, Lettere ed Arti 130:313-327

Piñeiro-Corbeira C, Barreiro R, Cremades J (2016) Decadal changes in the distribution of common intertidal seaweeds in Galicia (NW Iberia). Mar Environ Res 113:106-115

Pullin A, Frampton G, Jongman R, Kohl C, Livoreil B et al (2016) Selecting appropriate methods of knowledge synthesis to inform biodiversity policy. Biodivers Conserv. doi:10.1007/s10531-016-11319

Polo L, Olivella I, Gili C, Anadón R, Altamira C, Ros JD (1982) Primera aportación a la sistemática de la flora y fauna bentónicas del litoral de San Ciprián de Burela (Lugo, Galicia). Actas I Simposio Ibérico de Estudios del Bentos Marino pp 337-375

Quetglas A, Morales-Nin B (2004) Age and growth of the ommastrephid squid Todarodes sagittatus from the western Mediterranean sea. J Mar Biol Assoc UK 84:421-426

Raybaud V, Beaugrand G, Goberville E, Delebecq G, Destombe C, Valero M, Davoult D, Morin P, Gevaert F (2013) Decline in kelp in West Europe and climate. PLoS ONE 8:e66044

Reisewitz SE, Estes JA, Simenstad CA (2006) Indirect food web interactions: sea otters and kelp forest fishes in the Aleutian Archipelago. Oecologia 146:623-631

Ribera MA, Gómez-Garreta A, Gallardo T, Cormaci M, Furnari G, Giaccone G (1992) Check-list of Mediterranean Seaweeds. I. Fucophyceae (Warming 1884). Bot Mar 35: 109-130

Rico JM, Álvarez Raboso J, Llera EM (2009) Desaparición de los bosques de Laminarias en la costa de Asturias. Asturnatura 26:25-27

Rinde E, Rygg B, Bekkby T, Isæus M, Erikstad L, Sloreid S-E, Longva O (2006) Documentation of modelled marine nature types in DN's Naturbase. First generation of models for the municipalities mapping of marine nature types. NIVA report 5321-2006 
Rinde E, Christie H, Fagerli CW, Bekkby T, Gundersen H, Norderhaug KM, Hjermann DØ (2014) The influence of physical factors on kelp and sea urchin distribution in previously and still grazed areas in the NE Atlantic. Plos One: e0100222

Robuchon M, Le Gall L, Mauger S, Valero M (2014) Contrasting genetic diversity patterns in two sister kelp species co-distributed along the coast of Brittany, France. Mol Ecol 23:2669-2685

Rueness J, Fredriksen S (1991) An assessment of possible pollution effects on the benthic algae of the outer Oslofjord, Norway. Oebalia 17:223-235

Schiel DR, Foster MS (2006) The population biology of large brown seaweeds: ecological consequences of multiphase life histories in dynamical coastal environments. Annu Rev Ecol Evol Syst 37:343-372

Schindler S, Livoreil B, Sousa Pinto I, Araújo R, Zulka K-P, Santamaría L, Euller K, Kropik M, Wrbka T (2013) Fina knowledge assessment reports of the 3 case studies and lessons learned. Deliverable 3.1 of the EU-FP7-project KNEU, contract No. 265299. http://biodiversityknowledge.eu/documents

Schindler S, Sebesvari Z, Damm C, Euller K, Mauerhofer V, Hermann A, Biró M, Essl F, Kanka R, Lauwaars SG, Schulz-Zunkel C, van der Sluis T, Kropik M, Gasso V, Krug A, Pusch M, Zulka KP, Lazowski W, Hainz-Renetzeder C, Henle K, Wrbka T (2014) Multifunctionality of floodplain landscapes: relating management options to ecosystem services. Landscape Ecol 29:229-244

Schindler S, Livoreil B, Sousa Pinto I, Araújo R, Zulka K-P, Pullin AS, Santamaría L, Kropik M, Fernández-Méndez P, Wrbka T (2016) The network BiodiversityKnowledge in practice: insights from three trial assessments. Biodivers Conserv. doi:10.1007/s10531-016-1128-4

Schories D, Selig U, Jegzentis K, Schubert H (2005) Klassifizierung der äußeren Küstengewässer an der deutschen Ostseeküste nach der europäischen Wasserrahmenrichtlinie anhand von Makrophyten-Eine Zwischenbilanz. RMB 14:135-150

Schoschina EV (1997) On Laminaria hyperborea (Laminariales, Phaeophyceae) on the Murman coast of Barents Sea. Sarsia 82:371-373

Schramm W (1999) Factors influencing seaweed responses to eutrophication: some results from EU-project EUMAC. J Appl Phycol 11:69-78

Seoane Camba J (1957) Algas superiores de las rías bajas gallegas. Investigaciones Pesqueras 8:15-28

Sfriso A, Facca C (2013) Annual growth and environmental relationships of the invasive species Sargassum muticum and Undaria pinnatifida in the lagoon of Venice. Estuar Coast Shelf S 129:162-172

Silberfeld T, Racault MLP, Fletcher R, Couloux A, Rousseau F, De Reviers B (2011) Systematics and evolutionary history of pyrenoid-bearing taxa in brown algae. Eur J Phycol 46:361-377

Simkanin C, Power AM, Myers A, McGrath D, Southward A, Mieszkowska N, Leaper R, ÓRiordan R (2005) Using historical data to detect temporal changes in the abundances of intertidal species on Irish shores. J Mar Biol Assoc UK 85:1329-1340

Sivertsen K (1997) Geographical and environmental factors affecting the distribution of kelp beds and barren grounds and changes in biota associated with kelp reduction at sites along the Norwegian coast. Can J Fish Aquat Sci 54:2872-2887

Sivertsen K, Hopkins CCE (1995) Demography of the echinoid Strongylocentrotus droebachiensis related to biotope in northern Norway. In: Skjoldal HR, Hopkins C, Erikstad KE, Leinaas HP (eds) Ecology of fjords and coastal waters. pp 549-572

Skadsheim A, Christie H, Leinaas HP (1995) Population reductions of Strongylocentrotus droebachiensis (Echinodermata) in Norway and the distribution of its endoparasite Echinomermella matsi (Nematoda). Mar Ecol Prog Ser 119:199-209

Smale DA, Vance T (2015) Climate-driven shifts in species distributions may exacerbate the impacts of storm disturbances on northeast Atlantic kelp forests. Mar Fresh Res 67:65-74

Smale DA, Burrows MT, Moore P, Connor NO', Hawkins SJ (2013) Threats and knowledge gaps for ecosystem services provided by kelp forests: a northeast Atlantic perspective. Ecol Evol 3:4016-4038

Smale DA, Wernberg T, Yunnie ALE, Vance T (2015) The rise of Laminaria ochroleuca in the Western English Channel (UK) and preliminary comparisons with its competitor and assemblage dominant Laminaria hyperborea. Mar Ecol 36:1033-1044

Smale DA, Burrows MT, Evans AJ, King NJ, Yunnie ALE, Moore PJ (2016) Linking environmental variables with regional-scale variability in ecological structure and standing stock of carbon within kelp forests in the United Kingdom. Mar Ecol Progr Ser 542:79-95

Stegenga H, Karremans M, Simons J (2007) Zeewieren van de voormalige oesterputten bij Yerseke. Gorteria 32:125-143

Steneck RS, Graham MH, Bourque BJ, Bruce J, Corbett D, Erlandson JM, Estes JA, Tegner MJ (2002) Kelp forest ecosystems: biodiversity, stability, resilience and future. Environ Conserv 29:436-459

Steneck RS, Leland A, McNaught DC, Vavrinec J (2013) Ecosystem flips, locks, and feedbacks: the lasting effects of fisheries on Maine's kelp forest ecosystem. Bull Mar Sci 89:31-55 
Strain EM, Thomson RJ, Micheli F, Mancuso FP, Airoldi L (2014) Identifying the interacting roles of stressors in driving the global loss of canopy-forming to mat-forming algae in marine ecosystems. Glob Chang Biol 20:3300-3312

Strayer DL, Eviner VT, Jeschke JM, Pace ML (2006) Understanding the long-term effects of species invasions. Trends Ecol Evol 21:646-651

Suriano C, Mazzola S, Levi D, Giusto GB (1992) La biocenosi dei sub- strati duri circalitorali a grandi Phaeophyceae (Laminaria rodriguezii Bornet, 1988) nel Canale di Sicilia e nel Canale Maltese. Oebalia 17:429-432

Valero M, Destombe C, Mauger S, Ribout C, Engel CR, Daguin-Thiebaut C, Tellier F (2011) Using genetic tools for sustainable management of kelps: a literature review and the example of Laminaria digitata. Cah Biol Mar 52: 467-483

Valiela I, Mcclelland J, Hauxwell J, Behr PJ, Hersh D, Foreman K (1997) Macroalgal blooms in shallow estuaries: controls and ecophysiological and ecosystem consequences. Limnol Oceanogr 42:1105-1118

Veiga AJ, Cremades J, Bárbara I (1998) A catalogue of the marine benthic algae of the Sisargas Islands (N.W. Iberian Peninsula, Spain). Boletim del Museo Municipal de Funchal 5:481-483

Veiga P, Torres AC, Rubal M, Troncoso J, Sousa-Pinto I (2014) The invasive kelp Undaria pinnatifida (Laminariales, Ochrophyta) along the north coast of Portugal: distribution model versus field observations. Mar Pollut Bull 84:363-365

Voerman SE, Llera E, Rico JM (2013) Climate driven changes in subtidal kelp forest communities in NW Spain. Mar Environ Res 90:119-127

Voisin M, Engel C, Viard F (2005) Differential shuffling of native genetic diversity across introduced region in a brown alga: aquaculture versus maritime traffic effects. Proc Natl Acad Sci USA 102:5432-5437

Watson J, Estes JA (2011) Stability, resilience, and phase shifts in rocky subtidal communities along the west coast of Vancouver Island, Canada. Ecol Monogr 81:215-239

Wernberg T, Thomsen MS, Tuya F, Kendrick GA, Staehr PA, Toohey BD (2010) Decreasing resilience of kelp beds along a latitudinal temperature gradient: potential implications for a warmer future. Ecol Lett 13:685-694

Williams SL, Smith JE (2007) A global review of the distribution, taxonomy, and impacts of introduced seaweeds. Ann Rev Ecol Syst 38:327-359

Wiltshire KH, Malzahn AM, Wirtz K, Greve W et al (2008) Resilience of North Sea phytoplankton spring bloom dynamics: an analysis of long-term data at Helgoland Roads. Limnol Oceanogr 53:1294-1302

Yesson C, Bush LE, Davies AJ, Maggs CA, Brodie J (2015) Large brown seaweeds of the British Isles: evidence of changes in abundance over four decades. Estuar Coast Shelf Sci 155:167-175

Zampino D, Martino VD (2000) Presentazione cartografica dei popolamenti a materiali e metodi discussione e considerazioni conclusive. Biol Mar Mediterr 7:599-602

Zuljevic A, Antolic B, Nikolic V, Isajlovic I (2011) Review of Laminaria rodriguezii records in the Adriatic Sea. Posters Eur J Phycol 46:109-194 